\title{
Recent Advances in Technology, Strategy and Application of Sustainable Energy Systems
}

\author{
Wenxiao Chu ${ }^{1}$, Francesco Calise ${ }^{2, *(\mathbb{D}}$, Neven Duić ${ }^{3}{ }^{(0}$, Poul Alberg Østergaard ${ }^{4}(\mathbb{D}$, \\ Maria Vicidomini ${ }^{2}$ and Qiuwang Wang ${ }^{1}$ (D) \\ 1 Key Laboratory of Thermo-Fluid Science and Engineering (Ministry of Education), Xi'an Jiaotong University, \\ Xi'an, Shaanxi 710049, China; wxchu84@xjtu.edu.cn (W.C.); wangqw@mail.xjtu.edu.cn (Q.W.) \\ 2 Department of Industrial Engineering, University of Naples Federico II, P.le Tecchio 80, 80125 Naples, Italy; \\ maria.vicidomini@unina.it \\ 3 Faculty of Mechanical Engineering and Naval Architecture, University of Zagreb, Ivana Lučića 5, \\ 10000 Zagreb, Croatia; neven.duic@fsb.hr \\ 4 Department of Planning, Aalborg University, Rendsburggade 14, 9000 Aalborg, Denmark; poul@plan.aau.dk \\ * Correspondence: frcalise@unina.it; Tel.: +39-0817682301
}

Received: 3 September 2020; Accepted: 5 October 2020; Published: 8 October 2020

\begin{abstract}
The global COVID-19 pandemic has had strong impacts on national and international freight, construction and tourism industry, supply chains, and has resulted in a rapid decline in the demand for traditional energy sources. In fact, research has outlined that urban areas depend on global supply chains for their day-to-day basic functions, including energy supplies, food and safe access to potable water. The disruption of global supply chains can leave many urban areas in a very vulnerable position, in which their citizens may struggle to obtain their basic supplies, as the COVID-19 crisis has recently shown. Therefore, solutions aiming to enhance local food, water and energy production systems, even in urban environments, have to be pursued. The COVID-19 crisis has also highlighted in the scientific community the problem of people's exposure to outdoor and indoor pollution, confirmed as a key element for the increase both in the transmission and severity of the contagion, on top of involving health risks on their own. In this context, most nations are going to adopt new preferential policies to stimulate the development of relevant sustainable energy industries, based on the electrification of the systems supplied by renewable energy sources as confirmed by the International Energy Agency (IEA). Thus, while there is ongoing research focusing on a COVID 19 vaccine, there is also a need for researchers to work cooperatively on novel strategies for world economic recovery incorporating renewable energy policy, technology and management. In this framework, the Sustainable Development of Energy, Water and Environment Systems (SDEWES) conference provides a good platform for researchers and other experts to exchange their academic thoughts, promoting the development and improvements on the renewable energy technologies as well as their role in systems and in the transition towards sustainable energy systems. The 14th SDEWES Conference was held in Dubrovnik, Croatia. It brought together around 570 researchers from 55 countries in the field of sustainable development. The present Special Issue of Energies, specifically dedicated to the 14th SDEWES Conference, focuses on four main fields: energy policy for sustainable development, biomass energy application, building energy saving, and power plant and electric systems.
\end{abstract}

Keywords: sustainable energy; emission reduction; biomass; fuel conversion efficiency; building energy conservation; electric system 


\section{Introduction}

Here in 2020, COVID-19 is spreading rapidly all over the world and its impact extends from the global health system to the world economy, including the energy field [1]. Due to the contraction and even disruption of trade, the energy market and the situation of traditional energy resources (oil and natural gas) has been vigorously shocked. Considering energy security [2,3], the exploitation of renewable energy sources has become more important and imperative for countries that lack fossil fuels [4]. Meanwhile, environmental protection and emission reduction are gaining increasing importance around the world [5]. The application of renewable energy sources shows great potential for emission reduction [6,7], thereby more and more countries are promoting their energy strategy by shifting from fossil energy to renewable energy. In 2012, the Office of the European Union (EU) issued an Energy Roadmap [8], providing EU milestones from 2020 to 2050. With the implementation of relevant measures, $\mathrm{CO}_{2}$ emissions may be reduced by between $80 \%$ and $95 \%$ in comparison to the reference level in 1990. On the other hand, according to the Statistical Review of World Energy published by British Petroleum [9], the contribution by China, India and other Asian countries may occupy two thirds of the increase in global energy consumption before 2040, thus EU targets do not suffice and emission reductions in Asia must attract the same attention. Of course, with finite resources and competing needs, the development of sustainable energy systems should be achieved in a cost-effective way $[10,11]$.

The 14th conference on Sustainable Development of Energy, Water and Environment Systems (SDEWES) provides a favorable and efficient platform for academic communications. The papers introduced in this Special Issue (SI) are mainly cited from articles presented SDEWES conference series, especially at SDEWES 2019 Conferences. A total of 13 papers out of 511 accepted manuscripts were selected for publication in this Special Issue of Energies.

The cooperation between Energies and SDEWES since 2017 has already won acclaim from readers and has generated a greater international influence for both the journal and the conference, which will be continuously proceeded with greater success [12].

The papers in the present Special Issue can be categorized into four main research fields (Figure 1), including the energy policy for sustainable development (three papers), biomass energy application (two papers), building energy saving (four papers), and power plant and electric systems (four papers).

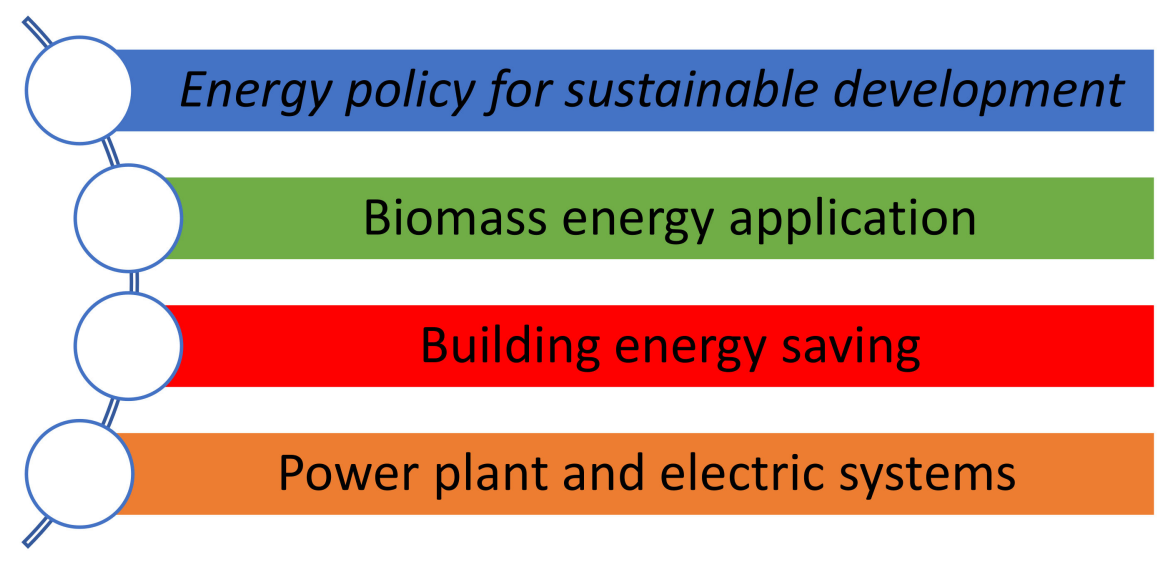

Figure 1. Main research fields.

These papers are all introduced in Section 3. Meanwhile, based on recent advances in technology, strategy and application of sustainable energy systems, papers presented in prior SDEWES Special Issues are also reviewed in Section 2. The contents include economic analysis, biomass energy application, building energy saving, energy storage technology and pollutant emission reduction. Figure 2 shows the distribution of the papers, included in the SDEWES conferences, as a function of the section and the publication year. Note that more than half of articles were published in the past two 
years. Meanwhile, almost $90 \%$ of the cited articles were published between 2015 and 2020. For articles published in 2017, the average citation number after one-year publishing is about $2-5$, which might reach 4-7 and 6-9 for papers published in 2018 and 2019, respectively. It is indicated that the SDEWES conference has been highly approved and will continuously use its influence to push forward the process of sustainable energy development.

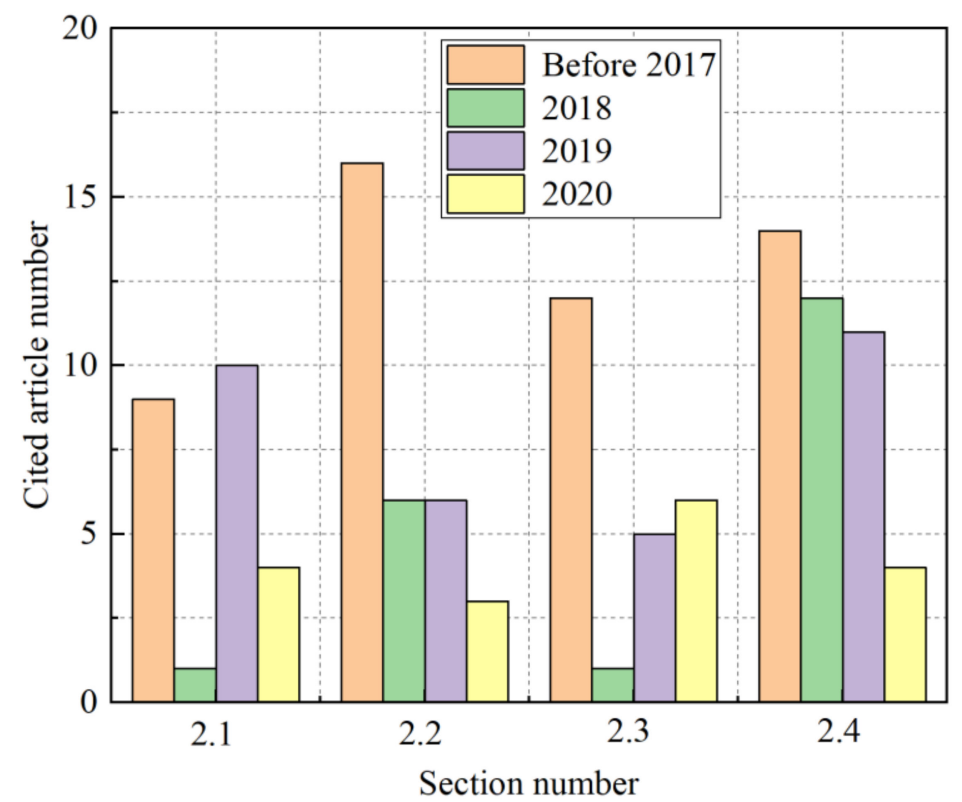

Figure 2. Distribution of papers citation number in each section and years distributions.

In the 21st century, fossil fuels are still the primary energy supply, which cover almost $80-85 \%$ of world energy demand. Serious environmental problems have emerged, thus efforts to replace fossil fuels with sustainable energy have become more imperative. The energy policy for sustainable development is not conceived as a technical process. However, it can promote application from socio-technical aspects. Burke and Stephens [13] categorized the applied policies to four socio-technical transitions. Lee and Min [14] analyzed the effect of firm construction on sustainable energy development based on manufacturing aspects. Wei et al. [15] predicted that over 4 million jobs related to renewable energy products will be created when keeping the aggressive sustainable development measures. Hartwig et al. [16] clarified that a positive impact on renewable energy development can be found after promoting employment through energy efficiency policy.

On the other hand, the technical developments always show intuitive promotion on energy conservation and emission reduction systems. Biomass energy application has shown great importance in the energy sector for green development. Bert et al. [17] developed a patented reactor using metal-enriched poplar biomass from contaminated soil. Vicente and Alves [18] reported various types of stoves and boilers for different types of biomass sources. Aghaalikhani et al. [19] first proposed the gasification process of plant-assisted bioremediation biomass and analyzed the impact after poplar biomass was contaminated. Soltero et al. [20] highlighted that the heat loss, heat storage and energy sources integration have become the key concerns, which are very challenging and should be focused by researches.

In the building environment, the energy utilization efficiency is limited and a high energy saving potential exists. Mazzarella [21] discussed various typical energy-saving measures for different levels of building applications. Ferrari and Riva [22] studied and evaluated the utilization of a vapor barrier on the inner side of an envelope, which can help for warming insulation. Blázquez et al. [23] investigated different ventilation system scenarios and developed an energy-saving criterion considering the thermal 
comfort and energy efficiency. Salem et al. [24] suggested replacing existing double-glazed windows with triple-glazed ones, which can notably reduce the heat loss of UK hotel buildings.

Usually, the variation of renewable energy sources in time, e.g., solar and wind, impedes their efficient utilization, and thereby strongly impact the supply fluctuation in power plant and electric systems. Hence, the energy storage system has been regarded as the most promising candidate solution to bridge the mismatch between the energy supply and demand. Hast et al. [25] studied the application of thermal energy storage apparatus in a direct heating system, which can produce much more renewable electricity as well as reduce the impact of the fluctuation of the electricity supply. Xu and Wang [26] built a single-stage thermal storage cycle, composed of charging and cooling subsystems. The system could improve the concentration glide at fixed operating temperature. Xu et al. [27] proposed the basic structure of multi-microgrid systems and studied the interactions between sub-grids and main grids. Lund et al. [28] introduced and emphasized the development of smart energy systems, including an individual energy sector and coupling sectors between electrification and storage.

\section{Background}

The papers published in pre-2019 SDEWES Special Issues are introduced in this section. With the consideration of the recent advances in technology, strategy and application of sustainable energy systems, papers in five fields are reviewed in this section-economic analysis, biomass energy application, building energy saving, energy storage technology and emission reduction.

\subsection{Energy Policy for Sustainable Development}

Since global warming became a main agenda-setting issue, much effort has been made with studies on efficient utilization and transition away from the utilization of fossil energy sources [29]. In recent decades, the strategy of maintaining a single energy supply pattern has been developed into a comprehensive strategy with multiple strategic goals and interactions [30]. Current economic policies and technology applied in Korea [31], Malaysia [32], Ghana [33] and China [34] were investigated. Usually, the investment cost of the transition from the traditional energy-dependent strategy to a renewable one should be carefully evaluated, and the economic feasibility is highly determined by raw materials, output quantity and output price [35]. Hence, appropriate policies were employed to incentivize the shift to a more sustainable society, with a low cost, more stability and a widespread market [36]. Valino et al. [37] investigated the economic impacts after changing the energy supply from relying on traditional energy resources to renewable ones. They noted that the risk aversion strategy should be introduced in the medium-to-long-term investment, which might lower the impact of uncertainty. The economic analysis aims to study the feasibility of strategy adjustment and upgrade in relevant energy industries, involving many fields, e.g., coal-fired efficiency [38], heat recovery and storage [39], battery storage [40], $\mathrm{CO}_{2}$ capture [41], electricity supply with renewable energy promotion [42], drying process [43], HVAC (heating ventilation and air conditioning) [44], etc. Meanwhile, the process of energy production [45] and transmission [46] as well as the negative effects on the environment such as pollutant emission [47] and the greenhouse effect [48] should be considered.

Roefs et al. [41] proposed an economic model in the $\mathrm{CO}_{2}$-enhanced oil recovery process. The environmental economic trade-off analysis was introduced, which is capable of estimating the global warming potential (GWP) of various $\mathrm{CO}_{2}$ capture scenarios. The results show that the GWP may reach $11 \mathrm{MtCO}_{2}$ equivalents during 10 years of oil and electricity production, which might be significantly decreased to $3.4 \mathrm{MtCO}_{2}$ for 15 years after applying the $\mathrm{CO}_{2}$ capture and storage system. This means that, while storing $\mathrm{CO}_{2}$ in the depleted reservoirs, the GWP might be six times lower over the same period. The net present value (NPV) analysis showed that a profitable business to capture $\mathrm{CO}_{2}$ in the enhanced oil recovery industry can be reached when maintaining a low $\mathrm{CO}_{2}$ price (not higher than $15 \mathrm{EUR} / \mathrm{t}$ ) and high oil price (not lower than $115 \mathrm{EUR} / \mathrm{t}$ ) on the market. On the other hand, the cost might accordingly rise after applying $\mathrm{CO}_{2}$ capture and storage systems. Yet the NPV still has benefits and the global warming potential could be pronouncedly reduced. Wiesberg et al. [49] 
also mentioned that carbon capture and storage pose a great economic penalty to power generation. It was suggested that authorities should support the shared investments of $\mathrm{CO}_{2}$ capture installations. With the development of economic mechanisms, both oil producers and large $\mathrm{CO}_{2}$-emitting firms could be mandated in depleted oil fields. The economic analysis was also applied to plastic pollution reduction, which has become a global issue. The pyrolysis recycling technology for mixed plastic waste has gradually grown and becomes mature in recent decades, and is regarded as a promising type of thermochemical recycling method. Larrain et al. [50] demonstrated the discrepancy of pyrolysis technology with closed-loop and open-loop schemes from the point of view of economic performance. A probabilistic study was adopted to approach the most important variables. It was found that open-loop pyrolysis shows superior economic value in comparison to closed-loop recycling because of its high prices of wax compared to naphtha. Yet a high dispersion emerged because of the volatility of the prices of crude oil and its derivates. When assuming that oil prices could be reduced with decarbonized electricity, the probability of a positive NPV reduced from $98 \%$ to $57 \%$. In contrast, for closed-loop recycling, the NPV reduced from $57 \%$ to less than $8 \%$. These results suggest that the transition to a circular economy can be achieved when the security of the value chain is introduced as part of policy incentives. Meanwhile, the attractiveness of the recovery alternatives would be raised while the provision of plastic feedstock for pyrolysis companies can be promised. The confidence of investors towards this type of technology might be increased if the recycled products market can be separated from the oil market.

In remote areas and relatively isolated environments, the development of sustainable energy paradigms is more and more important, where fossil fuels are more expensive due to the high cost of transportation and storage. In the meantime, renewable energy, having abundant resource availability, is highly competitive and holds a large potential for development. Bertheau [51] presented an energy system modelling to non-electrified islands in the Philippines from the perspective of technological and economical aspects. Simulations were proposed with all renewable energy systems by combining solar power, wind power and battery storage systems. It was found that the best cost-optimal system configuration should include solar power combined with battery storage, while wind power acts as a supplementary energy source. Since huge upfront investments were required, supportive policies should be addressed by policy makers and financing institutions in order to provide lower interest rates and lower revenue expectations. Hence, a lower capital cost can be achieved for wider deployment of renewable energy systems. Economic analysis has been also widely used for the development of energy-efficient buildings. Picallo-Perez et al. [52] proposed a dynamic thermo-economic analysis methodology for building energy systems. They noticed that the cost fractions is strongly related to capital investment. Meanwhile, the efficiency of air-conditioning systems was investigated by using a thermo-economic method, aiming to give support for decision makers from the technical side. The market price of components, total energy inputs as well as the $\mathrm{CO}_{2}$ emissions were preliminarily defined from the assessment of exergoeconomic and exergoenvironmental costs. Then, the trend of monthly cost was analyzed. The examined case indicated that the final outputs of the plants can be attributed to the fan-coils in the air-conditioning systems who suggested the highest monetary value in a school building. Conversely, components of the chiller, the cooling coil and the heat recovery unit have the highest environmental impacts on the greenhouse gas emissions.

In addition to humanity's own production and habitation processes, the scarcity of transport infrastructure has become a urgent issue, especially for urbanized cities with the development of transportation. An environmentally sustainable, economically viable and efficient traffic network was expected to be developed by transport operators and planners with the purpose of traffic pressure relief. A soft traffic management (STM) strategy was proposed by Kuang et al. [53], which can proactively analyze the traffic impact of transport planning measure. The effectiveness after implementing STM for reducing the greenhouse gas pollution was studied following a pilot research project in Logan City, Australia. By employing a multi-stage analysis and a stakeholder-based modelling procedure, it was indicated that the traffic congestion can be significantly relieved by introducing an extended busway. 
In addition, the proposed STM strategy also shows great promotion of environmental protection and efficiency improvement of the whole transport system.

\subsection{Biomass Energy Application}

Biomass energy comes directly or indirectly from the photosynthesis of green plants and it is stored in biomass carriers such as crops [54], plants [55], vegetation [56], waste frost [57] and wood [58], spent coffee grounds [59], Scenedesmus [60] and microalgae [61], etc., in the form of chemical energy. The energy stored in biomass is abundant, which is eligible to be converted into biosolid [62], bio-oil [63] and biogas [64] fuels or directly co-firing with conventional fuels (e.g., coal [65]). The utilization of biomass energy has made great progress in developed countries, considering the management and production costs [66]. Meanwhile, the application of biomass energy has become more favorable in the energy sector in developing countries for achieving sustainable development [67]. The application situation and the development potential of biomass energy in Italy [68], Croatia [69], Japan [70] and China [71] were studied. Kilkis [72] proposed a sustainable innovation index to compare the development ability of countries (Brazil, Russia, India, China, South Africa, Turkey and Singapore). The index could align priorities according to the feasibility of renewable systems for sustainable development. The authors noted that Singapore obtained the highest evaluation score and South Africa obtained the lowest score among the emerging and innovative economies.

The biomass production efficiency and environmental standards in existing technologies are the main limitative factors for the development of renewable energy [73]. Meanwhile, the operating cost is another concern that prevents the development from becoming more economically viable [74]. For achieving an optimal and long-term sustainable biomass technique, Vukasinovic et al. [75] developed an analytical methodology in which the interaction between mathematical optimization and back-casting approach was considered. A long-term planning process was evaluated by considering a large number of factors such as the raw material required, planning and resource management, supply chains, and corresponding conversion facilities. A case study for maximizing the utilization of forest residues was presented for one municipality in Serbia. Necessary changes have been defined and the optimal amounts of biomass as well as the most suitable method for its utilization were identified under current operating conditions. As a result, the frequency of its utilization was minimized and the distribution of the capacity of the installed power plant was improved to fulfill the heating load regionally. Ancona et al. [76] presented a comprehensive investigation of the contaminants and the energy consumption yielded in a plant-assisted bioremediation (PABR) biomass gasification process. Since contaminants accumulating in the roots are compounded by negligible tree trunks and branches, pruning residues was suggested in the gasification process in order to prevent additional contaminant emission. It was also found that calcium in the soil as well as that in the biomass always shows a moderate catalytic effect on the tar cracking improvement. Caputo et al. [77] evaluated the technical features and the thermal performance of a district heating plant with biomass energy, which were fueled by wooden chips. A database was developed and compiled for comparing the technical features of different technologies, considering the energy, environmental and economic performance. The advantages of exploiting a programmable and suitable biomass source were concluded with the consideration of climate change, environmental protection, and the reduction and saving of fossil fuels. On the other hand, some active ingredients in wasted burning products, such as potassium salts and silica, are applicable in agriculture industry. Additionally, potassium salt might also be extracted from ashes, which displays important gaseous salt species during biomass combustion. Wang et al. [78] developed a multi-step extraction method in a high-temperature environment, whereby available salt can be obtained from straw and woody biomass ashes. It was found that potassium always exists in two forms in extractive products, namely potassium chlorides and sulfates. In addition, the results show that cotton straw ashes have a much higher initial extraction ratio in comparison to the wheat straw ashes and sawdust ashes. The method suggested a more feasible utilization option for biomass solid wastes. As the bulk density of the material increases, a higher conversion efficiency 
can be achieved [79]. Additionally, the high deposition and corrosion risk were also observed when straws/wood are used as input material for boilers.

Since replacing fossil fuels by biofuels has become an irresistible trend, indirect greenhouse gas emissions produced by biofuels and other sustainable energy sources were also a big concern-for example, the land-use change, carbon leakage and biomass transportation [80]. Research indicated that the above indirect factors were capable of reversely raising the $\mathrm{CO}_{2}$ emissions, even totally offsetting the benefits of $\mathrm{CO}_{2}$ sequestration from the utilization of biofuels. Ko et al. [81] presented an example of biofuel production by using agricultural residues in the Great Mekong Subregion. The carbon balance with different bioenergy production scenarios was calculated, and the results show that significant amounts of $\mathrm{CO}_{2}$ were generated when improper techniques were applied for waste management, such as open-ground burning and onsite dumping. Research also revealed that the conversion of the biomass to biogas or bioethanol production and the application of the co-combustion technique with biomass residues can maintain about 98,161 to 488 teragrams of $\mathrm{CO}_{2}$, respectively, hence a pronounced reduction can be obtained. In the meantime, the saving techniques will not only alleviate the environmental impact of anthropogenic activities, but also provide good reliability without jeopardizing food security.

Usually, deposits from biomass combustion contain plenty of soot or char [82]. The properties of soot and char may differ from particles with elemental carbon, organic carbon and other organic compounds. Ruzickova et al. [83] tested the deposits generated by the combustion of hardwood briquettes in boilers. The authors found that the char from emissions of boilers contains alkanes and cycloalkanes, nitriles, carboxyl acids, anhydro-saccharides, phytosterols and PAHs by approximately $80 \%, 80 \%, 50 \%, 230 \%$ and $180 \%$, respectively. Wang et al. [84] further studied the high-temperature soot formation mechanism with the synergistic effect of biomass and polyurethane co-pyrolysis. A fixed-bed reactor was implemented where individual pyrolysis of plastic (polyurethane) with biomass (wheat straw and wood) and co-pyrolysis of polyurethane with biomass were respectively measured. The results indicate that the co-pyrolysis method of plastic with biomass might produce biochar. The release of volatile compounds was effectively restrained and the soot formation was consequently deteriorated. When co-pyrolysis of wood and polyurethane is applied, the deterioration might become more severe. By raising the pyrolysis temperature, the influence of the synergistic effect on the soot formation might be further weakened. Nonetheless, the increase in biomass addition ratio for co-pyrolysis might result in a smaller diameter range of soot particle size.

\subsection{Building Energy Saving}

The processes of building material production, building construction and structure utilization consume plenty of energy [85]. Meanwhile, it was clarified that the operating energy costs are several orders of magnitude higher than those of construction when considering the lifespan of a building [86]. In order to achieve a higher building efficiency, a complex system should be designed considering the HAVC system [87], building envelope and appearance [88], electric system [89], energy harvesting apparatus [90], intelligent control of system operation and occupant activities [91], aiming to provide occupants with a comfortable and safe environment.

Since the modelling of actual energy profiles of buildings at the district level is unpractical, Ferrari et al. [92] accomplished a review of 70 studies in the scientific literature and defined a set of criteria, aiming to classify the contributions with the consideration of the energy demand and sources. The proposed criteria were applicable for stakeholders who are responsible for community energy planning and energy simulations of building stocks. The demand of building energy with different desired levels could be accurately accessed. Meanwhile, the research also demonstrated that the dataset availability mainly constrains the replicability of analyzed methods. Basically, the reduction in energy consumption and environment pollution during construction as well as the energy-saving measures after establishment are the main concerns for designing energy-efficient buildings [93]. Efforts for improving the energy efficiency of a building's full lifecycle have been targeted in two main directions: one is the upgrade of envelope elements (e.g., façade [94], windows [95], roofs [96], 
etc.), and the other is the improvement of applied facilities (e.g., heating, cooling [97], ventilation [98] and lighting [99]). The building envelope, which is another responsible architectural component of energy-saving efficiency in buildings, may also significantly impact their thermal comfort [100] and energy balance [101]. Krstic-Furundzic et al. [102] presented the estimation of energy performances of an office building in Belgrade's climate conditions. The proposed assessment scenarios included the consideration of energy demands and actual consumption for heating and cooling by implementing different shading devices. As a result, the contributions of various alternative shading strategies for the reduction in total energy demand and environmental pollution were specified. The proposed model proved to be applicable for new building design as well as the renovation of existing office buildings in places that possess similar climatic conditions to Belgrade. The roof is another main part that affects the building's energy performance. The choice of roof materials and the implementation of appropriate energy-saving technologies may pronouncedly affect the thermal performance of buildings [103]. Ramos and Aires [104] built a small-scale prototype of a dwelling house and experimentally studied its thermal environment. The influence of natural ventilation of a roof cavity under Mediterranean summer conditions was analyzed. The result shows that the daily fluctuations of indoor air temperature are attenuated, performing a favorable thermal time delay when implementing a ventilated roof and insulated panels. Moreover, it is validated that the natural ventilation constituted by a passive system indicates a crucial effect on the reduction in the temperature at the air-gap surfaces, suggesting a pronounced reduction in convective heat transfer to the roof attic.

The cooling demand and risk of overheating might be significantly reduced when efficient household appliances and the appropriate control measures were adopted. The historic buildings were barely considered in most energy-saving policies because the requirement for preservation is extremely rigorous and the feasible techniques for historic building dissemination is insufficient [105]. Tettey and Gustavsson [106] analyzed the energy renovation in a Swedish multi-story residential building in the 1970s. The energy savings and overheating risk were estimated under annual climate change. A variety of measures were considered to reduce cooling demand and overheating risk, including the application of an overheating control strategy, installation of energy-efficient windows and doors, and the utilization of ventilation with heat recovery systems. It was verified that the above technologies can give significant improvement on final and initial energy saving. When assuming that all measures were applied with the accumulation under current and future predicted climate scenarios, the energy consumption for space warming could be reduced by $58 \%$ and $54 \%$, respectively. Bottino-Leone et al. [107] developed a novel evaluation method for holistic buildings, which can perfectly retain the facades' integrity with the improvement in the envelopes' thermal transmittance. The hygrothermal risks were investigated through numerical simulation. Then, an energy assessment was presented after the evaluation of environmental impact and life-cycle energy consumption. The results indicate that initial environmental impact might reach the lowest level while material-based plants are utilized. In addition, retrofit interventions illustrated important implications to reduce the overall environmental impact associated with historic buildings. It was concluded that a design solution with the lowest environmental impact would be developed by choosing a proper indicator for historic buildings.

Occupant behavior is also a key variable which may noticeably affect the energy performance of buildings. When predicting energy performance and renewable exploitation in an actual building, the discrepancy of conventional models might reach up to $20 \%$ due to unforeseeable human behavior. Piselli and Pisello [108] monitored an office building, considering the real occupancy and peer occupants for 2 years. The neural response tests were adopted, and then a data-driven occupancy model was developed based on the collected data. The data-driven occupancy scenarios were trained via actual operating conditions in the real offices, which showed a more realistic trend of occupants' daily attitudes. Nevertheless, discrepancies still existed and a more generally representative model for predicting occupant behavior will be further developed through a human-centered design. 


\subsection{Power Plant and Electric Systems}

Despite the harmful impact on Earth's environment and human health, the combustion of fossil fuels dominates the position in the future electricity generation due to their abundance and corresponding low price [109]. In the exhaust gas, high concentrations of particulate matter are seen characterized when incomplete combustion occurs in engines [110]. Meanwhile, nitrogen oxides and carbon dioxide are the main contributors to the negative impact on the environment [111], which are generated in irregular and irresponsible agricultural practices [112], electricity generation [113], and transportation [114]. Researchers focused on the combustion processes of conventional solid and liquid fuels with inorganic or biomass additive to reduce pollutant emission [115]. Another effective method for achieving pollutant emission reduction is the application of $\mathrm{CO}_{2}$ carbon management technologies, including $\mathrm{CO}_{2}$ capture and storage, which is a competitive solution to mitigate global warming [116].

Interlenghi et al. [117] studied a large-scale offshore natural gas-fired power plant with high carbon dioxide content. The implementation of a supersonic separator was proposed to reduce $\mathrm{CO}_{2}$ emissions in the case of the expensive cost of carbon capture in the post-combustion process. For reducing the environmental pollution, the European Union allows the use of biofuel blending with conventional fuel for the internal combustion engines. Petranovic et al. [118] proposed a numerical model for pollutant prediction against experimental data. An average reduction in NO emissions might reach approximately $8 \%$. Vujanovic et al. [119] also developed a coupled Eulerian-Eulerian and Eulerian-Lagrangian method to describe spray, combustion and pollutant formation processes. It was observed that the prediction of temperature and pressure distributions, energy conversion efficiency and the total emission amount agreed with the experimental data very well. Chen et al. [120] investigated the combustion characteristics and exhaust emissions of a four-stroke single-cylinder diesel engine. Nanoparticles were blended with conventional diesel fuels, resulting in a significant reduction in brake-specific fuel consumption by up to $19.8 \%$. It was noticed that silicon oxide blends always displayed lower brake specific fuel consumption, lower carbon monoxide emissions and higher combustion pressure in comparison to aluminum oxide blends, suggesting much better results. Meanwhile, due to the significant improvement in NO emissions, the carbon nanotube was regarded as a potential additive after the issue of combustion stability was resolved. The preparation method might significantly affect the biomass particle size distribution, thereby impacting the overall combustion performance in a suspension-firing plant. Pyrolysis is also an efficient way to transform solid wastes into fuels. Then, renewable fuels can be used for internal combustion engines, showing an environmentally friendly economy. Vihar et al. [121] provided an in-depth quantitative measurement of the particulate emissions of the tire pyrolysis oil. The results show that diesel fuel produced by a tire pyrolysis process can pronouncedly reduce the soot emission by half, leading to a lower polyaromatic hydrocarbons content of tire pyrolysis oil. The discrepancies between soot emission and particulate matter emissions were identified via unique measurement technology. Yin [122] presented various biomass preparation methods for suspension-firing and reviewed the development and processes based on critical issues. When more low-grade biomass additives were utilized, more dedicated pretreatments such as the torrefaction process and pelletization were required in order to upgrade the feedstock quality. In addition, Somogyi et al. [123] found that effective heat reclamation shows positive promotion of the pollution removal. They analyzed a small Hungarian wastewater treatment plant and implemented some facilities to raise the temperature in the aerated tank by $6{ }^{\circ} \mathrm{C}$. As a result, the removal efficiency of ammonium could be improved by $61 \%$, indicating that the heat recovery strategy not only promotes energy saving, but also mitigates nutrient pollution.

$\mathrm{CO}_{2}$ emissions mostly correspond to energy generation, conversion, transmission and utilization. Bonaventura et al. [116] reviewed main $\mathrm{CO}_{2}$ capture and sequestration systems, aiming to achieve a near-zero $\mathrm{CO}_{2}$ emission power plant after the integration with renewables. It was found that the dry carbonate process possesses enormous advantages in comparison with other technologies in which a relatively low temperature $\left(<200{ }^{\circ} \mathrm{C}\right)$ is required for sorbent regeneration. Thus, it was proved 
that solar thermal power is eligible to assist $\mathrm{NaHCO}_{3}$ decarbonation. In the dry carbonate system, $\mathrm{Na}_{2} \mathrm{CO}_{3}$ might be converted to $\mathrm{NaHCO}_{3}$ after reacting with water steam and $\mathrm{CO}_{2}$, then $\mathrm{Na}_{2} \mathrm{CO}_{3}$ might be regenerated after condensation process, yielding a gaseous product containing $\mathrm{H}_{2} \mathrm{O}$ and $\mathrm{CO}_{2}$. It was estimated that the cost of $\mathrm{CO}_{2}$ capture ranges from 0.095 to $0.112 \mathrm{EUR} / \mathrm{kW}$ compared to $0.087 \mathrm{EUR} / \mathrm{kW}$ of electricity generation in the original plant. It was observed that there is still room for technology improvement on the dry carbonation process, indicating that additional cost saving could be expectedly achieved. Puksec et al. [124] studied the future energy demand and corresponding GHG emissions in Croatia and appropriate energy saving measures were implemented. When assuming that the implemented policies were well executed, the predicted final energy demand in 2030 might reach a level $43 \%$ lower than that projected by the Croatian National Energy Strategy. Meanwhile, the energy demand and the maximum GHG emission savings in 2050 could be lowered by about $16 \%$ and $60 \%$, respectively, compared to that in 2010. Schneider et al. [125] quantitively evaluated the amount of recovered energy from municipal solid waste in Croatia. Effective measures, including electricity generation from landfill gas, utilization of refuse-derived fuel, solid-waste incinerations with thermal and mechanical-biological treatment, were proposed, whereby substantial GHG emission savings could be achieved. It was predicted that the $\mathrm{CO}_{2}$ emissions can be reduced by about 1 million tons in 2020, equating about $2.7 \%$ of the Croatian projected GHG emissions. Meanwhile, the energy recovered from solid waste may reach $8.3 \mathrm{PJ}$ in 2020 . The equivalent value is about $3 \%$ of the total final energy consumption of Croatia in 2008. Gladysz and Ziebik [126] proposed a lifecycle assessment strategy based on the thermo-ecological cost in an integrated oxy-fuel combustion power plant combined with $\mathrm{CO}_{2}$ capture, storage and transport processes. The authors noted that the thermo-ecological cost of an analyzed coal-fired power plant in Poland might rise about $22 \%$ after applying a carbon capture and storage system with near-zero emission. It was proved that the operation cost reaches over $99.5 \%$, showing a dominant proportion. In contrast, the construction, repair and decommissioning phases of infrastructure for $\mathrm{CO}_{2}$ transport and storage could be ignored. Nawi et al. [127] presented a systematic technique via a graphical visualization tool for developing cost-effective $\mathrm{CO}_{2}$ emission reduction strategies in industries. An approach in the palm oil refinery was identified where the $\mathrm{CO}_{2}$ emissions were reduced by $31.2 \%$ after implementing the systematic technology. An initial investment of USD 38,212 was required, with a payback period of 10 months based on the present energy prices in Malaysia. Fan et al. [128] revealed that the greenhouse gas and air pollutants were not simultaneously evaluated, thereby the interaction between different pollutants was not adequately considered. With the purposes of optimizing the carbon management strategy, they developed a graphical decision-support method which can determine the most economical pathway for biomass resources utilization [129]. The strategy was also adapted to environmental footprints and processes of other non-GHG emissions. Meanwhile, the indirect and secondary impacts were considered in the analysis considering the data uncertainties. The results indicate that pyrolysis of biomass always represents a preferable choice in terms of its emission-cost performance, unless soil could be amended by the biochar. It was also suggested that pyrolysis optimized for biochar production has priority for France and Denmark. Meanwhile, pyrolysis optimized for energy production is preferred for Japan. It was also observed that the graphical nature of the method is capable of facilitating communication between final decision-makers and experts.

The match scope of energy supply and demand is a big concern for creating practical planning strategies and policies at a sectorial level [130]. Basically, renewable energy (e.g., solar and wind) might fluctuate in winter and summer as well as during the day and night. Therefore, in order to mitigate the effects of intermittency, suitable energy storage systems are needed and the feasibility of energy storage systems is expected to become increasingly important in the near future due to the wider application of renewable energy and power quality [131]. Energy storage systems can be categorized into three species based on energy forms, district heating storage in thermal systems [132], electric energy storage in micro grid systems [133] and chemical energy storage for costless transport [134]. It was found that the hydrogen storage was widely utilized in regions with high wind power supply. In Europe, 
the electric storage with batteries, currently, is much preferable [135]. Moster et al. [136] introduced the utilization of innovative energy storage technologies, including thermal energy storage systems with compressed fluid, power-to-heat-to-power storage systems, and reversible storage systems by solid oxide fuel cells.

Jin et al. [137] developed a real-time dynamic simulator for a power plant with a maximum capacity of $500 \mathrm{MW}$. The operation characteristics of the frequency control system was investigated during a breakdown process, and a high-capacity energy storage system was applied to minimize the fluctuation of the power grid. Luburic et al. [138] examined the importance of the energy storage process for raising the power system adequacy and security in Croatian power system. The installation of energy storage system can preserve the system within its operating limits, provide enough time for the grid redispatch and relieve the overloaded lines when a contingency occurs. The simulation results show that the construction of a new transmission line is the best solution for preventing blackouts on the Istrian peninsula in the power plant. However, it might be a lengthy project and the project would get stuck due to steep terrain or legal issues. An alternative option was the installation of battery storage system, which would provide a more secure provisional operation until the new transmission line was scheduled and constructed. For minimizing the annual operational cost for a modal residential consumer in Belgian, Milis et al. [139] established various household microgrid configurations with variable electricity prices and tariff schemes. Management and determination insights for policy makers were provided based on the results of different simulated system configurations, including a power grid without battery storage systems, a power grid with battery storage only, and that with battery storage and decentralized renewable energy production with photovoltaic (PV) panels. It was indicated that the capacity block pricing strategy could only certainly incentivize the utilization of battery storage system as one imperative part for PV installation. In addition, the combination of real-time pricing and capacity block pricing policies would pronouncedly promote the adoption of battery storage. In the electric vehicle market, the electric storage capability and its high investment cost is the bottleneck that limits the development of electrical vehicles [140]. Calise et al. [141] presented a thermo-economic analysis for combining electric energy storage (EES) system and photovoltaic energy considering the environmental impact, which suggests a novel sustainable mobility goal. After introducing EES systems with lead-acid and lithium-ion battery schemes, the amount of electrical energy transported from the public grid is reduced by $12 \%$ and $19 \%$, respectively. The corresponding $\mathrm{CO}_{2}$ emissions reduction might reach about $67-72 \%$.

Researchers pointed out that the electric storage compactness shows a crucial effect on commercial applications and the technology might become much more profitable after a notable reduction in the investment cost [142]. On the other hand, not only the high cost, but also a serious safety issue has been raised over the application of large-scale energy storage in batteries [143]. Thermochemical energy storage can offer a low pressure and low seasonal energy requirement at high energy densities [144]. It was predicted that thermal energy storage and hydrogen storage may develop rapidly and have the most promising applications in the future [145]. Dominkovic and Krajacic [146] built an integrated model to optimize the share of district energy supply versus individual cooling and reduce the operating costs in energy systems with and without proper energy storage solutions in Singapore. Different types of optimal PV configurations with virous large-scale energy storages were detected, and the results reveal that the share of district cooling with $30 \%$ showed the optimal efficiency. Bohm and Lindorfer [147] examined the economic applicability of thermochemical materials applied for heat storage in district heating systems. The district heating grid for supply, the charging location of the energy sources and the corresponding transfer distance indicated major influence on the selection of suitable thermochemical storage (TCS) materials. The authors noted that hydration-based TCS materials (hydrates and hydroxides) are preferable if the costs for material transport and the water vapor supply are ignored. Metallic TCS materials were more suitable for cases with greater spatial distance between the energy source and the grid system due to their high storage densities. The study 
also provided promising pre-selection criteria of relevant TCS materials with applications in district heating systems.

The energy storage via chemical substances and compressed combustible gases is also crucial [148]. Pospisil et al. [149] evaluated the economic efficiency of liquefied natural gas (LNG) for the direct and indirect storage of cold energy. Existing data indicated that the involved technologies may seriously affect the overall efficiency of LNG systems for operative energy storage. The liquefaction process is capable of removing most of the impurities contained in natural gas, thereby cleaner fuel and significant volume reduction can be reached. Considering the boil-off effect and energy consumption by compressors, the transport of LNG by specialized carriers is more energy efficient compared to that of compressed natural gas transported by gas pipelines. When transporting flexible energy over long distances, LNG is preferable to be employed as an energy storage medium with the combination of efficient liquefaction technology for energy charging and regasification technology for energy recovery. Carneiro et al. [150] presented the principle for first screening of potential energy storage sites based on geological and regional assessments in Portugal. It was proposed that the adequate geological distribution with porous rocks, salt formations and igneous host rocks is the best location that could be regarded as a candidate reservoir for storing hydrogen, methane, compressed air, etc. Since natural gas storage in salt formations has been carried out for decades, the energy storage would indicate strong reliability and demonstrate high social acceptance. Moreover, porous media aquifers located at the Lusitanian basin on the western coast of Portugal were also identified as potential reservoirs. The Sines industrial cluster in southwest of Portugal was considered as another capable target area with the existence of a host rock with proven containment capacity.

\section{Research Topics Represented in this Special Issue}

A total of 13 papers from 14th SDEWES Conferences were selected for this special issue. The main ideas and conclusions of these papers are briefly reviewed in the following subsections.

\subsection{Energy Policy for Sustainable Development}

Wagner et al. [151] analyzed sustainable business models to be implemented for the long-term survival of companies in the framework of the energy transition. In particular, they focused on the changes in the electricity sector regime in Germany (Figure 3).

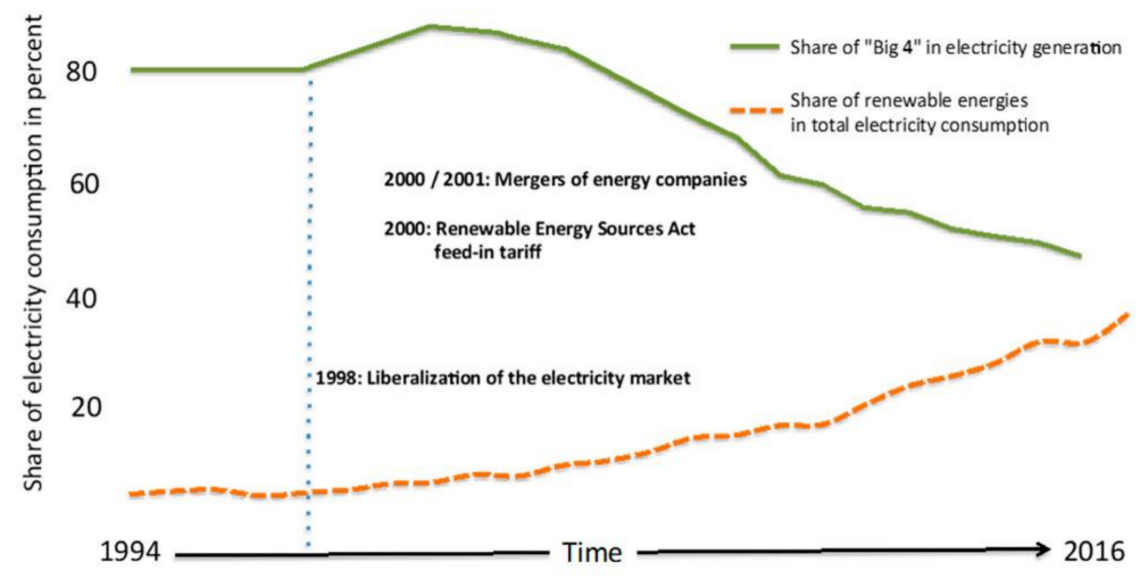

Figure 3. Electricity sector in Germany. Reproduced from [151], Energies: 2020.

As for the majority of the EU countries, this sector, during the past few decades, has mainly been monopolistic or oligopolistic, dominated by four main companies. Only after 2015 did the market share of these four companies decrease below $50 \%$, due to the liberalization of the energy markets. With the gradual improvement of humans' awareness for environmental protection, sustainable and 
renewable energies are becoming increasingly competitive, and have shown great growth recently in order to achieve national economic and climate targets. Generally, economic development indicates greater energy requirement; however, conventional electricity generation declined from 501 to $437 \mathrm{TWh}$ from 2009 to 2017 because of the strategic mistakes of Germany's Big4 companies in the past who are experiencing an economic crisis in these sectors. In addition, the energy transition in Germany dramatically affected the structure of the energy market, changing the core business of the companies and their self-image. It was predicted that the earnings contribution will be considerably lower, and the trend will continuously drop with the energy transition progresses. The multi-level perspective (MLP) was proposed to analyze the electricity market over the past 50 years. It was proved that the MLP is an applicable and effective tool for structuring the external impacting factors on business models over time. As the climate targets of emissions should be reduced by $80-95 \%$ in 2050 in comparison to that in 1990, the prevailing principles were not adequate enough or were too isolated to provide sufficient demand for a rapid change in the electricity sector regime. Thus, profitable business models as well as new sustainable business strategies become imperative to reverse the current situations. Against this background, a proposal for the evaluation of sustainable business models was developed. Authors also provided five potential business examples and investigated their feasibility, including the rollout of public infrastructure for e-mobility, supply of system solutions, dynamic pricing for electricity utilization, digitalization from the demand side and digitalization from the supply side. In addition, five criteria were also defined in order to evaluate the feasibility of these business models. These criteria are: climate targets, client acceptance, low costs, fast implementation, and competitiveness. The MLP approach was used to identify the factors that facilitated the fall of the four main companies. It showed that start-ups have to develop novel business ideas for contesting with big companies. The e-mobility example suggested that changes in the electricity sectors allow companies from other fields of enterprise (e.g., transport), which can offer serious competition. Such new competitors, usually, were well-funded, which is different from most start-ups who have enormous demand for investment to form capital-intensive assets. Meanwhile, the example with digitalization from both the demand side and the supply side suggested that electricity consumers have long-term relationships with electricity companies who can benefit from their traditional activities. Innovative solutions could be implemented via a premium on electricity tariffs. As the result, customers barely need to undertake the prepayment for electricity consumption.

As is well known, most countries do not have rich and adequate energy resources. Their energy consumption is constantly rising and makes geopolitical and international relations even more complex. The existed tensions include the varying intensity, the introduction of sanctions and armed conflicts. The analysis for a specific area may be extremely complex, due to the plurality of influencing factors and due to large ambiguities. For achieving energy security, a number of countries are developing dynamic energy policies with the combination with other applicable and suitable policies. Decisions were made with different approaches by progressing from subjective assessment to multi-attribute decision making. These decisions are based on both reliable and measurable variables and on a number of alterable and questionable variables. Therefore, it is urgent to develop a more reliable and robust decision-making tool, especially for the energy sector. Presently, no clearly established procedure or methodology is available in this field. In this framework, Podbregar et al. [152] analyzed model settings of the International Energy Security Risk Index which was developed by the U.S. Chamber of Commerce. This index is representative of the most reliable and complex approach available in this field. This approach simultaneously takes into account a plurality of different variables, including technical, environmental and economic factors to evaluate and forecast the energy security. An example was enumerated with a set of 29 input variables, and 25 OECD (Organization for Economic Co-operation and Development) member countries were considered for the period of 1980 to 2016. This index is based on the evaluation of 29 indicators, ranging from transportation sector to the fuel costs and availability. Methodologies with stepwise regression, Promax oblique rotation and principal component analysis were adopted by the authors. The results based on basic stepwise regression 
indicate that the two common variables involving the crude oil prices and global coal reserves can only explain $90 \%$ of the variance of the index. It was also predicted that, when the variance of the index was explained by $100 \%$, the Global Coal Reserves variable would completely lose its significance due to the contained effect of other variables. In other words, the applied variables had complex interactions which make them impossible to analyze independently. In addition, the analysis also illustrated that a total of twelve variables (including World Oil Refinery Usage, Energy Consumption per Capita, GDP per Capita, Transport Energy per Capita, $\mathrm{CO}_{2}$ per Capita, Energy Intensity, Petroleum Intensity, Transport Energy Intensity, $\mathrm{CO}_{2}$ GDP Intensity, Electricity Diversity, Non-Carbon Generation and $\mathrm{CO}_{2}$ Emissions Trend) play an important role. However, other variables involving GDP and GDP-related variables as well as variables related to transportation, environmental and electricity issues would describe a satisfactory degree of grouping. Hence, a revision of the International Energy Security Risk Index was imperative and highly recommended, thereby the variables without any contribution can be removed for achieving a higher precision. It was concluded that the main advantage of the revised index is with respect to the fact that variables are categorized within different generality levels and the interactions should be considered.

On the other hand, scientific studies are important for constructing a sustainable society; however, a study performed in a top-down manner with Sustainable Development Goals (SDGs) has not been devised and conducted. Researchers are crucial for achieving important advancements in several sectors. As an example, the development of a new sustainable energy paradigm is mainly based on the new developments performed by scientific research. To understand the bottom-up research activities, Asatani et al. [153] developed a citation network analysis and natural language processing methodology. More than 300,000 publications related to sustainability were involved. They used the terms "sustainability" and "sustainable" as keywords in their research. They found more than 0.5 million papers and they also observed that the number of publications has rapidly increased in the past few years. The methodology returned 312,584 academic papers which were classified using 163 clusters. The authors focused on 23 clusters, including more than 1000 papers. It was suggested that diverse and dynamic changes in sustainability science have occurred over the last few years. Significant correspondence between the sustainability research subjects and SDGs were diagramed after examining the relationship between them. The authors noted that SDG topics, such as "inclusive society" and "early childhood development", were discussed in academic studies by following a convergent approach. The convergence of terms was observed in the citation network. A series of new topics, e.g., nanocellulose and global health, have become more attractive for scientists who are planning new research topics. These topics indicate great implications which gradually attract widespread academic interest. The results indicate valuable predictions and indirect experience for government officials. Moreover, private companies and academic researchers were also empowered to understand the research progress devoted to SDGs. Currently, most of the academic papers containing the terms of "sustainability" or "sustainable" were not included, which also contribute to sustainability research. A model considering the major differences in word usage between the SDGs and academic publications should be further developed to enable more accurate analysis. Additionally, the model update is also important, as the model may become out-of-date in merely a few years.

\subsection{Biomaas Energy Application}

Due to the serious impact of fossil fuel on the environment and human health, the shift from conventional energy to renewable energy strategies is experiencing unprecedented development. The substitution of fossil fuel-based materials by biomaterial-based products is an inevitable trend. Therefore, it is still imperative to explore much rawer biomaterials and novel environmentally friendly resources, aiming to reduce the pressure of currently available renewable energy supply.

Anaerobic digestion (AD) is one of the most attractive processes in the field of energy recovery by biomass. $\mathrm{AD}$ is a very mature technology and it is currently used in a huge number of energy plants. In addition, significant research effort has also been performed in order to develop novel and 
more efficient systems. In this framework, Alrefiai R. et al. [154] introduced the response surface methodology (RSM), which is a popular design of experiment techniques to study the impacts of the starch on biogas productions from the anaerobic digestion (AD) of potato peels. The progresses before and after starch separation were investigated and compared. A specific amount of the potato cultivar named "Golden Wonder" was focused on due to its high contents of starch. Then, the Hollander beater was implemented for both the potato peels pre-treatment and starch isolation. The study is based on experiments which were carried out in a lab-scale batch system. Figure 4 illustrates the apparatuses and equipment that were utilized in the preparation of the samples for the AD process.

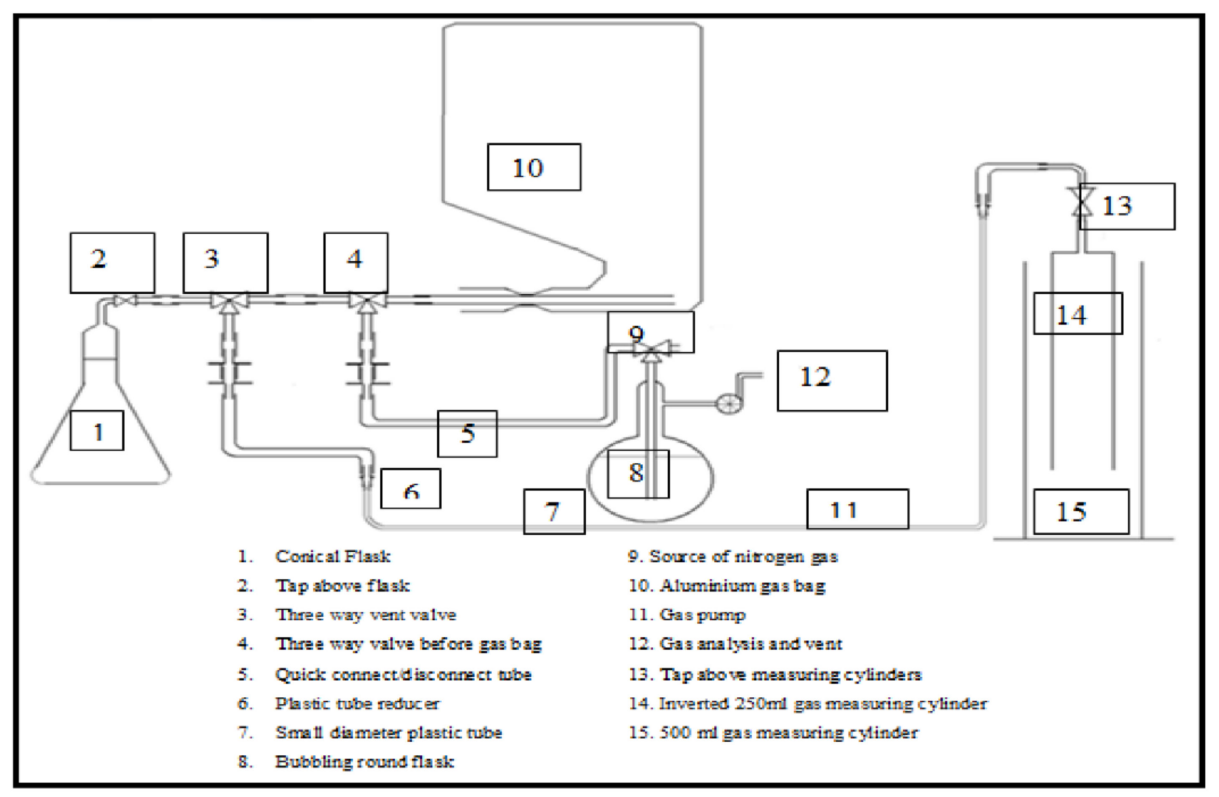

Figure 4. Apparatuses and equipment used in the preparation of the samples. Reproduced from [154], Energies: 2020.

Variables including the amount of isolated starch, particle size, volatile fatty acid (VFA) and the $\mathrm{pH}$ were all considered during the experimental test. The results show that the highest energy increase for potato peels reaches $62.9 \%$ with the temperature of $35^{\circ} \mathrm{C}$, organic concentration by $1.62 \mathrm{~g}-\mathrm{VS} / 0.2 \mathrm{~L}$ and sludge concentration by $50 \%$. The corresponding $\mathrm{CH}_{4}$ yields a maximum value of $72.4 \%$. It was found that the biogas volume production with the unit of $\mathrm{g}-\mathrm{VS} / 0.2 \mathrm{~L}$ was proportional to the sludge concentration. However, it was inversely proportional with the organic concentration, which shows the most negative effect on the improvement of biogas volume per $\mathrm{g}-\mathrm{VS} / 0.2 \mathrm{~L}$. Meanwhile, the generation efficiency of $\mathrm{CH}_{4}$ was significantly influenced by the sludge and organic concentrations. The interaction between them also showed an insignificant effect. The increasing rate of $\mathrm{CH}_{4}$ might be pronouncedly reduced when increasing the sludge concentration and decreasing the organic concentration. In addition, the interaction between the organic concentration and the sludge concentration shows an insignificant effect when the organic concentration reached the highest level. However, its role might become greater as the organic concentration decreases. As the result, it was revealed that the starch always possesses a slight impact on the quantity of biogas product and an even much lower impact on its quality. For further mitigating the environmental impact and economical obstacles of $\mathrm{AD}$ and constructing a more commercially attractive technology, the authors suggested further investigating the comprehensive utilization of other starch-based products for producing biogas and bio-slurry simultaneously.

Cassava is a food largely available in several countries. It is rich in starch and several bio-products can be obtained by this starch, which can be profitably used for energy purposes. Cassava peel has a much greater weight proportion (about $20-25 \%$ in one cassava), which is much higher than that in potato peel (about $12.5 \%$ in one potato). Alrefai A. et al. [155] investigated the biogas generation by 
starch isolated from cassava peel via the AD process. The quantity and quality of biogas production were both considered. The study was focused on cassava coming from Costa Rica. The analyzed cassava was manually peeled and cut into small parts in order to promote the treatment process. Pre-treatment by a beating process was performed. This substrate was collected from a treatment plant in Kildare, Ireland, which was subsequently mixed with the sludge. The effects of substrate temperature, volatile solid quantity and sludge quantity were analyzed, and three criteria were used in terms of produced biogas quantity and quality, sales of AD plants from dealers and target of the sludge quantity. As aforementioned, the rare influence of the starch on the biogas quality was found, indicating a negligible effect. The results show that the highest biogas volume might reach $4.2 \mathrm{~g}$-VS at the temperature of $37{ }^{\circ} \mathrm{C}$ and sludge quantity by $50 \%$. The maximum $\mathrm{CH} 4$ might reach $850 \mathrm{cC}$ per g-VS biogas volume. Accordingly, the highest percentage of the biogas was $1442.5 \mathrm{cc}$ per g-VS. On the contrary, the lowest amount of biogas produced was 831 cc per g-VS when the system was operating at the lowest temperature with the lowest volatile solid value at fixed sludge quantity by $37.5 \%$. In this case, the $\mathrm{CH} 4$ concentration was rapidly reduced. The lowest volume of the biogas with $479.7 \mathrm{cc}$ per g-VS was achieved at the conditions of $34{ }^{\circ} \mathrm{C}, 2.65 \mathrm{~g}$-VS biogas volume and sludge quantity by $25 \%$. Meanwhile, a stable and cheap feedstock of cassava peels would give a higher biogas production, indicating that shorter payback periods are needed for the involved investment of AD facilities. In this regard, authors recommended that the lab-scale is capable of being performed in large-scale and practical production in reality. It was also concluded that starch has a low impact on the biogas production. Future studies should focus on other factors such as the organic loading rate and retention time. It was also suggested to investigate starch from other food wastes and compare results to the progress without extracting starch reported in other related literature. In summary, the accumulation and combination of the digestate and $\mathrm{AD}$ processes as well as the economic analysis of maintaining the digestate condition still remain challenging. Hence, the sustainability of AD should be further enhanced to reduce the dependence on fossil fuel and there is still room for improvement.

\subsection{Buiding Energy Saving}

In Europe, buildings have accounted for over $40 \%$ of the total energy consumption. Increasing the energy efficiency of buildings by improving the performance of heating and cooling facilities becomes more and more essential. The implementation of a ground source heat pump and district heating system has proven capable of reducing energy consumption in buildings. Encouraging building owners to perform refurbishments in order to improve building envelope thermal performance also has benefits for energy-saving purposes. Roselli et al. [156] investigated the air-conditioning (AC) system of an office building. The AC system was served by a ground source heat pump in coupling with mini wind turbines (Figure 5).

The exceeding renewable electricity is supplied to the users for the appliances included in the building. Different plant configurations are considered. The dynamic method was developed to simulate the energy, environmental and economic potentials of the plant with renewable energy systems. The wind turbine technology, plant location and battery storage capacity were considered. Two kinds of wind turbines $(5-5.5 \mathrm{~kW})$ with horizontal and vertical orientations were introduced. Then, the influence of battery storage systems ranging from 3.2 to $9.6 \mathrm{kWh}$ was analyzed. Finally, the office buildings located in Naples and Cagliari were respectively analyzed. The proposed systems were dynamically simulated in a TRNSYS (17, University of Wisconsin-Madison: Madison, WI, USA) environment. Suitable dynamic simulation models were used for all the components included in the investigated layouts. In addition, a specific model was developed for the calculation of primary energy savings and the electricity exchange with the grid. The results show that the initial energy savings with respect to the final energy demand of users including pure electric load, space heating and cooling reached 1.24 in Cagliari and 0.56 in Naples. The environmental impact index of the proposed system suggested a pronounced reduction in greenhouse gas emissions, which can be expressed as kilogram $\mathrm{CO}_{2}$ per kWh of the final energy demand. For Cagliari, the index ranged between 0.151 and 0.288 , 
and this was between 0.068 to 0.151 for Naples. Meanwhile, the percentage of renewable electricity might rise when decreasing the wind turbine nominal capacity and increasing the battery storage size. For the case with one vertically oriented wind turbine and the battery storage capacity of $9.6 \mathrm{kWh}$, the percentage of renewable electricity might reach the highest value of $83.1 \%$. On the contrary, the storage system always showed restriction on the interaction with the power grid. The exported electricity might be lowered from $50 \%$ to about $27 \%$ and from $63 \%$ to $50 \%$ in Naples and Cagliari, respectively. Eventually, the fractions of renewable energy were maximized to $25 \%$ and $48 \%$ for Naples and Cagliari. Based on the economic analysis, a significant reduction in operating costs can be obtained due to the renewable system of wind energy despite the high initial cost of wind turbines, ground source heat pumps, borehole heat exchangers and electricity storage systems.

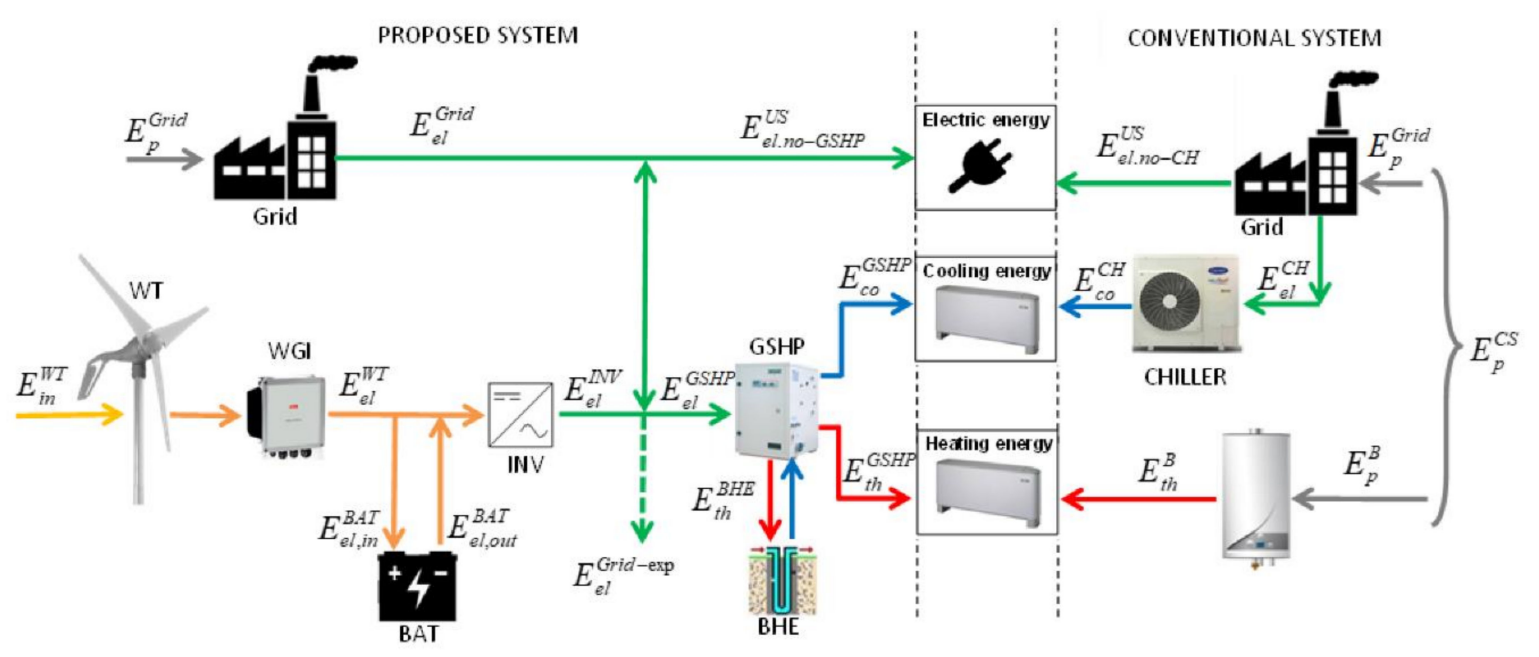

Figure 5. Proposed and conventional systems in heating and cooling configurations. Reproduced from [156], Energies, 2020.

As mentioned before, one of the technologies allowing one to significantly reduce a building's primary energy demand is the ground source heat pump. This technology provides both heating and cooling energy with a coefficient of performance much higher than those of conventional air-to-water heat pumps. This improvement is achieved by increasing the evaporation temperature or by reducing the condensation temperature, in winter and in summer, respectively. Therefore, it is crucial to perform an optimal design of the heat exchange between the fluid and the ground. This topic was analyzed by Vella et al. [157], presenting a study for the performance improvement of a ground-source heat pump. They focused on the effect of the distance between the two vertical U-tubes applied in a counter-flow heat exchanger. Two different heat exchangers with the depth of 20 and $40 \mathrm{~m}$ were individually modeled and numerically investigated. In particular, suitable CFD simulation models were purposely developed in ANSYS FLUENT (16.2, Canonsburg, Pennsylvania, USA). The distance between U-tubes ranged from 40 to $26 \mathrm{~mm}$, and the temperature drop from tube inlet and its outlet was predicted. Validation against similar experimental work was reported, which showed that the U-shaped connector at the bottom of the U-tube has a slight influence on the temperature profile of the working fluid. The results indicate that, for the cases with smaller distance, slight increment on the distance might result in an improvement in heat transfer by $4-7 \%$. Once the distance increased beyond $150 \mathrm{~mm}$, minor improvement could be found. On the other hand, improvements might reach as high as $55 \%$ when focusing on the results of cases across the specific depth. It can be concluded that the temperature drop from the inlet to outlet becomes more dependent on the pipe length rather than the distance for a ground source heat pump system with shallow U-tubes.

Building owners make large investments in novel sustainable energy supply technologies during the transition to renewable energy systems. In order to achieve an optimal economic-transition 
strategy, these investments in new facilities should be coordinated with the investments in energy and cost savings. With the development of the 4th generation of district heating systems, Djørup et al. [158] focused on smart energy systems where primary energy is supplied from sustainable energy sources with district heating sources. The analytical model was constructed from the perspective of local strategic heating policies, in which a novel assessment methodology should be introduced considering the influence of capital markets. Considering the current district heating tariffs, the authors examined the dataset of single-family houses which were constructed between 1961-1972 in Aalborg. The studied case indicated that the currently applied tariff structure provided insufficient financial incentive to building owners, making the investment not cost-effective. In addition, it was clarified that the fluctuations in the capital markets become a potential barrier when an economic system has been optimized and planned. On the other hand, it was predicted that the financial incentive for heat saving can be pronouncedly improved by implementing a fully variable heat tariff scheme. Meanwhile, the system development was very sensitive to fluctuations and shortages in the capital market. It was suggested that strategic policies in local district heating supplies and municipalities can be inspired. Then, there are potential long-term benefits for building owners with a 100 percent variable tariff.

Accordingly, a lower distributed temperature in district heating systems as well as a greater amount of heat saving can be achieved. In the meantime, the influence of investment decisions should be further examined by other cases and building types. Moreover, the model would be further improved after introducing the supply-demand imbalance and the marginal supply costs.

For minimizing the investments of sustainable energy, the selection of cost-effective facilities and the building envelope also play an important role for a sustainable building design. In terms of making effective and correct decisions, investigations on constructing and running costs throughout the lifespan of buildings become imperative. Pucko et al. [159] presented a new approach to estimate the comprehensive economic analysis building envelope components with automated or semi-automated methods. The building information modelling (BIM) method was introduced, providing a simple overview of all initial and operating costs in the lifecycle of buildings. A new preschool building in Maribor was tested and the external walls, roof systems and thermal isolation features were considered. As a result, the design with the lowest cumulative life-cycle costs as well as the design with the best cost efficiency were figured out. In this way, investors were easily to make the right decision without computing various variants. It provided a fast and efficient way while regarding the energy- and cost-effective variant as the target. In addition, the present methodology was applicable to other building envelope components for new or existing buildings with similar economic environments. The authors also demonstrated that, in order to accurately optimize the information transmission process and automation aggregation method, other variables which have a correspondingly lower impact on the efficiency of variant solutions should be further involved.

\subsection{Power Plant and Electric Systems}

The integrated gasification combined cycle (IGCC) is a widely used power production system for solid fuels, having the advantages of high efficiency and good environmental protection performance. Meanwhile, chemical looping combustion (CLC) is an effective route for emission reduction with the association of $\mathrm{CO}_{2}$ capture strategy, thereby the conversion efficiency will be correspondingly improved. Pozo et al. [160] investigated two IGCC power plants with the concept of $\mathrm{CO}_{2}$ capture and storage (CCS) coupled with gas switching combustion (GSC) looping and gas switching oxygen production (GSOP) technology. As for the gas switching reactor, a suitable transient model was developed in MATLAB, approaching a zero-dimensional prediction. Here, the system is simulated as a continuous stirred tank reactor. The power plant is modelled in Unisim Design R451. In addition, an exergy analysis methodology was applied to benchmark against one IGCC without $\mathrm{CO}_{2}$ capture and one pre-combustion $\mathrm{CO}_{2}$ capture IGCC plant. The exergy model is based on conventional exergy balances. The authors noted that the GSC IGCC plant displays a similar emission quality and efficiency, and the GSOP-GSC plant shows a slight thermal efficiency increase by approximately $1 \%$ in comparison to that 
in previous literatures. However, the capture ratio would be reduced by about $10 \%$ because of stream mixing into clusters at the outlet. Then, the authors developed a detailed energy-analysis diagram for almost all power plant configurations with the assistance of a modeling auxiliary tool, which is capable of determining the process streams of physical and chemical energy. The efficiency gains from the GSC IGCC plant related to the pre-combustion $\mathrm{CO}_{2}$ capture were achieved due to the lower syngas cooling, inherent carbon capture and hot gas clean-up strategies. When the GSOP technology is introduced, lower energy penalty could be achieved through the exergy analysis. By removing the air separation units and lowering the operating temperature in the Winkler gasifier, a substantially lower exergy destruction was obtained in the gasification island. Based on the obtained results, it is suggested that optimizations of the components where a large exergy destruction occurs might have the most improvement potential. Moreover, a parallel economic assessment should be further studied to examine the holistic benefits of potential exergy gains.

In the field of space research, the fuel conversion efficiency has become a significant limiting factor in the field of space exploration due to the higher price of rocket flights. Space exploration also has a significant environmental impact, due to the huge amount of gases released during the launch of rockets. Many different approaches to energy savings for the rocket flights have been tested, including the designs of different types of propellants, engine systems and their control, material issues in the combustion chamber and nozzle designs. SpaceX, founded by Elon Musk, introduced an innovative cost-saving concept. This company successfully returned a rocket to Earth after launching it into low Earth orbit. They also focused on the fuel consumption, in order to minimize the environmental impact when launching the rocket through the atmosphere. In this framework, Jozic et al. [161] evaluated several strategies which were applicable to reduce the fuel consumption during the flight of a Falcon Heavy rocket. The Falcon Heavy is a rocket developed by Space X. It is about 70 meters tall and it weighs about 1420 tons. The fuel utilized in the Falcon Heavy rocket was a kerosene (RP-1) and liquid oxygen (LOX). They aimed at reducing the cost of rocket flights in order to promote the expansion of this sector, also reducing its environmental impact. The main goal is the optimization of the flight trajectory. A real flight was simulated by using a suitable computational model, purposely developed by the authors. The model evaluated the time dependence of the mass flowrate and the related energy consumption. It was indicated that reducing the amount of fuel in the side thrusters is the best fuel-saving strategy, thereby the rocket could dump them after their running out of fuel as soon as possible. The dependence of the final energy on the fuel saving amount was predicted by numerical simulations with the reduction in fuel amount. The reduction in the initial fuel mass can be treated as the fuel savings by matching the final total energy of the empty rocket in the numerically modelled flight and that in the real flight. Theoretically, in their computational model, the fuel-saving in rocket could reach 35.5 tons, which occupies $2.7 \%$ of the total initial fuel in the real flight. Hence, the studied strategy has significant potential to reduce the environmental impact of burning fossil fuels as well as the cost during rocket launches, which is also applicable for Mars exploration in the near future. The conversion efficiency of fuels in rocket flights would be further improved.

The improvement in thermal efficiency of conventional power systems is an effective way to achieve the reduction in fuel consumption as well as carbon emissions. Jamaluddin et al. [162] applied Pinch Analysis to an extended Trigeneration System Cascade Analysis (TriGenSCA). This technique was employed to optimize the geometrical size of power, heating and cooling components in a trigeneration system under dynamic operating conditions. Their methodology includes the pinch analysis, which is a well-known technique, widely used for the optimization of networks of heat exchangers. They coupled the pinch analysis with the Total Site Power, Heating and Cooling methodology. This technique focuses on the integration of all the heating, cooling and power components available at the site. A total of seven steps were involved, including data extraction, time slice identification, Problem Table Algorithm, Multiple Utility Problem Table Algorithm, Total Site Problem Table Algorithm, TriGenSCA, and Trigeneration Storage Cascade Table (TriGenSCT). The methodology considers the energy losses during energy conversion, electricity charging/discharging in power plant and the thermal energy 
storages. It also considers the energy requirement for the startup and continuous operation of the system. Meanwhile, the start-up and continuous operations in the total site system can be determined with the development of TriGenSCT. Then, the maximum geometrical size of power and thermal energy storages as well as the external energy demand for the system operation will be obtained. One case study was enumerated. The minimum total energy requirement of $57.42 \mathrm{GWh} / \mathrm{d}$ should be produced by pressurized water reactor (PWR, Figure 6) systems for meeting the demands in deficit energy district.

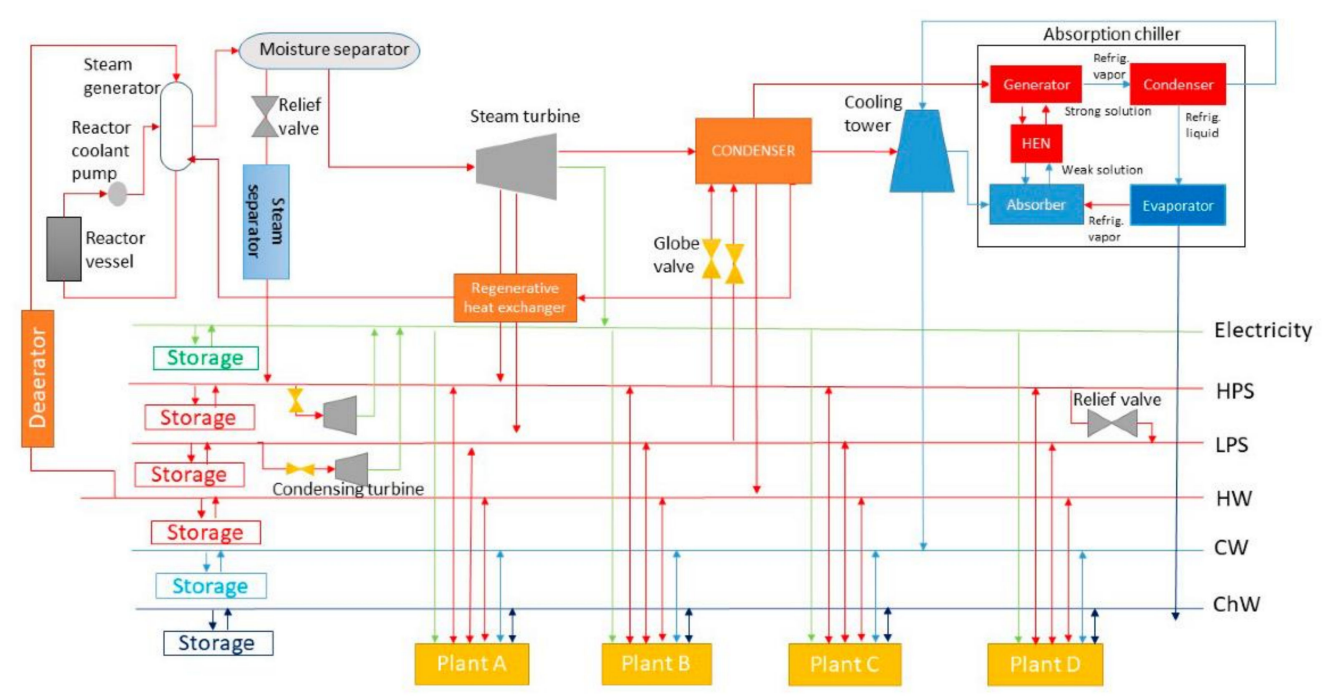

Figure 6. A graphic representation of the design of the pressurized water reactor nuclear power plant (PWR NPP) as a trigeneration system supplied energy to a Total Site. Reproduced from [162], Energies, 2020.

The energy demand was less than $0.3 \%$ in comparison with the trigeneration PWR without integrated optimization. Moreover, the corresponding annual cost and energy loss after introducing trigeneration PWR with integration could be reduced by $0.2 \%$ and $1.43 \%$, respectively. Currently, the study only regarded the PWR NPP as a nonintermittent centralized trigeneration system considering the demand variations. Future studies are needed to focus on the supply energy variation and the supply-demand integration in nuclear-hybrid renewable energy systems. The authors also concluded that their methodology could be used for the evaluation to optimally size the utilities in trigeneration system and evaluating the minimum energy in the total site.

Due to the strong fluctuation characteristics of sustainable energy, e.g., wind and solar power sources, energy should have adjustable features in space and time. For large networks, renewable power sources are developed with a high investment requirement, not only for power generation facilities, but also for their transmission and storage systems. The flow allocation (FA) method is capable of calculating the usage of the transmission grid and allocates the corresponding costs to each single market participant. Hofmann et al. [163] presented an extended mathematical model based on the power transfer distribution factor (PTDF). The model incorporated the prior and current operational states of controllable elements into high-voltage direct current power lines with the combination of Marginal Participation (MP) and Equivalent Bilateral Exchange (EBE) methodologies. Then, MP and EBEs algorithms were used in the extended method to analyze the low-carbon European Network of Transmission System Operators for Electricity (ENTSO-E), which includes five synchronous zones with different sizes. The electricity power was distributed via each synchronous zone through AC lines, and then, all power loads within the subnetwork would be balanced within a nominal operational state. The result indicates that the total transmission capacity volume could be expanded by $18 \%$ compared to that of today's operating condition when a spatial resolution of 181 nodes was applied. The allocating situations by MP and EBE methodologies also showed that countries with high wind 
potentials have the greatest benefit from the expansion of grid transmission. Based on the obtained results of transmission system expansion, the authors also proposed a method for appropriately distributing the operational and capital expenditures. As a result, injections from renewable resources would be clarified, suggesting strong driving force for the country-to-country energy allocations as well as the cross-border electricity swaps. For establishing a future scenario for the European power system, an optimized FA method should be developed to confirm the cross-border transactions. The transmission grid usage and the usage of transmission expansion of each country has to be quantitatively specified. Additionally, a possible distribution scheme is expected to be developed for evaluating the capital expenditures on transmission projects.

\section{Conclusions}

This Special Issue of Energies, dedicated to the 14th Sustainable Development of Energy, Water and Environment Systems Conference, held in 2019 in Dubrovnik, Croatia, provides an insight into topics related to sustainable development. A total of 511 oral presentations and 100 poster presentations were included at the conference. In addition, 17 special sessions, one special and one clustering event were held with some of the most distinguished experts in the relevant fields. The Guest Editors of this Special Issue believe that the selected papers presented recent advances in five main fields (energy marketing policy, electric system optimization, improvement of fuel conversion efficiency, biomass energy application and building energy conservation) will be extremely interesting for the readers of Energies.

The papers presented in this Special Issue clearly showed that the topic of energy policy is crucial in order to achieve the goals of a sustainable development and decarbonization established by many countries. In this framework, the use of suitable energy planning strategies, aiming at determining the optimal configurations of the novel energy strategies and the optimal mix of technologies to be used for future energy scenarios. In this context, biomass is one of the most attractive renewable energy sources, due to the large availability of this resource all over the world and due to the plurality of technologies presently available to convert biomass in energy or byproducts, such as anaerobic digestion, gasification, energy crops and many others. Another important key point to be addressed in order to achieve the goals of sustainable energy development is represented by the optimization of fossil fuel-based power plants. In fact, the transition to a fully renewable energy system will pass through the improvement of the efficiency of power plants, reducing the consumption of fossil fuels and also reducing greenhouse emissions. In this field, the integrated gasification combined cycle is probably the most attractive technology for its capability to use low-quality solid fuels, at extra-low greenhouse gases emissions. In addition, a sustainable development of nuclear power plant is also expected to enhance the environmental impact of electricity production, due to the null greenhouse gas emissions of nuclear power plants. Finally, the papers included in this Special Issue also pointed out that the reduction in building energy consumption is also crucial in order to reduce fossil fuel consumption and greenhouse gases emissions. In fact, in Europe, buildings account for over $40 \%$ of the total energy consumption. The goal of reducing building energy consumption may be primarily achieved by using novel and efficient HVAC systems, such as ground-source heat pumps, and/or integrating renewable technologies (mainly solar PV panels [164], solar thermal collectors [165] or PV thermal collectors [166]) in the building energy system.

Future SDEWES Conferences will further focus on the fields of sustainable development of energy, transport, water, food and environment systems, their integration, their technical, environmental, economic and social perspectives, etc. Meanwhile, the SDEWES Conferences will keep the pace with the developments in the field and provide an excellent platform for scientists and researchers. Additionally, the SDEWES committee will meet the challenge of the epidemic situation, disseminate new knowledge for shaping future and contribute to the sustainable development of the world. Information on the upcoming events and other related activities can be found on the website of the International Centre for Sustainable Development of Energy, Water and Environment Systems (SDEWES Centre). 
Author Contributions: Original draft preparation, W.C.; writing-review and editing, visualization, supervision, F.C., M.V., N.D., P.A.Ø. and Q.W. All authors have read and agreed to the published version of the manuscript.

Funding: This research received no external funding

Acknowledgments: The guest editors thank the authors of the papers that submitted their manuscripts to this special issue for the high quality of their work. Authors also thank all the reviewers who provided valuable and highly appreciated comments and advice, and the managing editors of Energies for their patience and excellent support.

Conflicts of Interest: The authors declare no conflict of interest.

\section{References}

1. Ghiani, E.; Galici, M.; Mureddu, M.; Pilo, F. Impact on Electricity Consumption and Market Pricing of Energy and Ancillary Services during Pandemic of COVID-19 in Italy. Energies 2020, 13, 3357. [CrossRef]

2. Graff, M.; Carley, S. COVID-19 assistance needs to target energy insecurity. Nat. Energy 2020, 5, 352-354. [CrossRef]

3. Guo, Y.; Hawkes, A. The impact of demand uncertainties and China-US natural gas tariff on global gas trade. Energy 2019, 175, 205-217. [CrossRef]

4. Eroglu, H. Effects of Covid-19 outbreak on environment and renewable energy sector. Environ. Dev. Sustain. 2020, 1-9. [CrossRef]

5. Jin, S. COVID-19, Climate Change, and Renewable Energy Research: We Are All in This Together, and the Time to Act Is Now. ACS Energy Lett. 2020, 5, 1709-1711. [CrossRef]

6. Streimikiene, D.; Lekavicius, V.; Balezentis, T.; Kyriakopoulos, G.L.; Abrham, J. Climate Change Mitigation Policies Targeting Households and Addressing Energy Poverty in European Union. Energies 2020, 13, 3389. [CrossRef]

7. Karlsdottir, M.R.; Heinonen, J.; Pálsson, H.; Palsson, O.P. High-Temperature Geothermal Utilization in the Context of European Energy Policy-Implications and Limitations. Energies 2020, 13, 3187. [CrossRef]

8. European Commission. Energy Roadmap 2050; Publications Office of the European Union: Luxembourg, 2012; Available online: https://ec.europa.eu/energy/sites/ener/files/documents/2012_energy_roadmap_2050_en_0. pdf (accessed on 8 October 2020).

9. Petroleum, B. BP Statistical Review of World Energy. Available online: //www.bp.com/content/dam/bp/ business-sites/en/global/corporate/pdfs/energy-economics/statistical-review/bp-stats-review-2019-fullreport.pdf (accessed on 8 October 2020).

10. Fortunski, B. Sustainable Development and Energy Policy: Actual $\mathrm{CO}_{2}$ Emissions in the European Union in the Years 1997-2017, Considering Trade with China and the USA. Sustainability 2020, 12, 3363. [CrossRef]

11. Fawcett, T.; Killip, G. Re-thinking energy efficiency in European policy: Practitioners' use of 'multiple benefits' arguments. J. Clean. Prod. 2019, 210, 1171-1179. [CrossRef]

12. Calise, F.; Costa, M.; Wang, Q.; Zhang, X.; Duić, N. Recent Advances in the Analysis of Sustainable Energy Systems. Energies 2018, 11, 2520. [CrossRef]

13. Burke, M.J.; Stephens, J.C. Energy democracy: Goals and policy instruments for sociotechnical transitions. Energy Res. Soc. Sci. 2017, 33, 35-48. [CrossRef]

14. Lee, K.-H.; Min, B. Green R\&D for eco-innovation and its impact on carbon emissions and firm performance. J. Clean. Prod. 2015, 108, 534-542. [CrossRef]

15. Wang, F.; Peng, X.; Wei, R.; Qin, Y.; Zhu, X.-H. Environmental behavior research in resources conservation and management: A case study of Resources, Conservation and Recycling. Resour. Conserv. Recycl. 2019, 141, 431-440. [CrossRef]

16. Hartwig, J.; Kockat, J.; Schade, W.; Braungardt, S. The macroeconomic effects of ambitious energy efficiency policy in Germany-Combining bottom-up energy modelling with a non-equilibrium macroeconomic model. Energy 2017, 124, 510-520. [CrossRef]

17. Bert, V.; Allemon, J.; Sajet, P.; Dieu, S.; Papin, A.; Collet, S.; Gaucher, R.; Chalot, M.; Michiels, B.; Raventos, C. Torrefaction and pyrolysis of metal-enriched poplars from phytotechnologies: Effect of temperature and biomass chlorine content on metal distribution in end-products and valorization options. Biomass Bioenergy 2017, 96, 1-11. [CrossRef] 
18. Vicente, E.D.; Alves, C.A. An overview of particulate emissions from residential biomass combustion. Atmos. Res. 2018, 199, 159-185. [CrossRef]

19. Aghaalikhani, A.; Savuto, E.; Di Carlo, A.; Borello, D. Poplar from phytoremediation as a renewable energy source: Gasification properties and pollution analysis. Energy Procedia 2017, 142, 924-931. [CrossRef]

20. Soltero, V.M.; Chacartegui, R.; Ortiz, C.; Lizana, J.; Quirosa, G. Biomass District Heating Systems Based on Agriculture Residues. Appl. Sci. 2018, 8, 476. [CrossRef]

21. Mazzarella, L. Energy retrofit of historic and existing buildings. The legislative and regulatory point of view. Energy Build. 2015, 95, 23-31. [CrossRef]

22. Ferrari, S.; Riva, A. Insulating a Solid Brick Wall from Inside: Heat and Moisture Transfer Analysis of Different Options. J. Arch. Eng. 2019, 25, 04018032. [CrossRef]

23. Blázquez, T.; Ferrari, S.; Suarez, R.; Sendra, J.J. Adaptive approach-based assessment of a heritage residential complex in southern Spain for improving comfort and energy efficiency through passive strategies: A study based on a monitored flat. Energy 2019, 181, 504-520. [CrossRef]

24. Salem, R.; Bahadori-Jahromi, A.; Mylona, A.; Godfrey, P.; Cook, D. Investigating the potential impact of energy-efficient measures for retrofitting existing UK hotels to reach the nearly zero energy building (nZEB) standard. Energy Effic. 2019, 12, 1577-1594. [CrossRef]

25. Hast, A.; Rinne, S.; Syri, S.; Kiviluoma, J. The role of heat storages in facilitating the adaptation of district heating systems to large amount of variable renewable electricity. Energy 2017, 137, 775-788. [CrossRef]

26. Xu, Z.; Wang, R. A sorption thermal storage system with large concentration glide. Energy 2017, 141, $380-388$. [CrossRef]

27. Xu, Z.; Yang, P.; Zheng, C.; Zhang, Y.; Peng, J.; Zeng, Z. Analysis on the organization and Development of multi-microgrids. Renew. Sustain. Energy Rev. 2018, 81, 2204-2216. [CrossRef]

28. Lund, H.; Østergaard, P.A.; Connolly, D.; Ridjan, I.; Mathiesen, B.V.; Hvelplund, F.; Thellufsen, J.Z.; Sorknses, P. Energy storage and smart energy systems. Int. J. Sustain. Energy Plan. Manag. 2016, 11, 3-14.

29. Tschulkow, M.; Compernolle, T.; Bosch, S.V.D.; Van Aelst, J.; Storms, I.; Van Dael, M.; Bossche, G.V.D.; Sels, B.F.; Van Passel, S. Integrated techno-economic assessment of a biorefinery process: The high-end valorization of the lignocellulosic fraction in wood streams. J. Clean. Prod. 2020, 266, 122022. [CrossRef]

30. Foley, A.; Olabi, A.G. Renewable energy technology developments, trends and policy implications that can underpin the drive for global climate change. Renew. Sustain. Energy Rev. 2017, 68, 1112-1114. [CrossRef]

31. Ko, D.-H.; Chung, J.; Lee, K.-S.; Park, J.-S.; Yi, J.-H. Current Policy and Technology for Tidal Current Energy in Korea. Energies 2019, 12, 1807. [CrossRef]

32. Cheah, K.W.; Yusup, S.; Singh, H.K.G.; Uemura, Y.; Lam, H.L.; Wai, C.K. Process simulation and techno economic analysis of renewable diesel production via catalytic decarboxylation of rubber seed oil-A case study in Malaysia. J. Environ. Manag. 2017, 203, 950-961. [CrossRef]

33. Lee, C.Y.; Lotsu, S.; Islam, M.; Yoshida, Y.; Kaneko, S. The Impact of an Energy Efficiency Improvement Policy on the Economic Performance of Electricity-Intensive Firms in Ghana. Energies 2019, 12, 3684. [CrossRef]

34. Dong, F.; Shi, L.; Ding, X.; Li, Y.; Shi, Y. Study on China's Renewable Energy Policy Reform and Improved Design of Renewable Portfolio Standard. Energies 2019, 12, 2147. [CrossRef]

35. Di Fraia, S.; Massarotti, N.; Prati, M.; Vanoli, L. A new example of circular economy: Waste vegetable oil for cogeneration in wastewater treatment plants. Energy Convers. Manag. 2020, 211, 112763. [CrossRef]

36. Tani, A.; Morone, P. Policy Implications for the Clean Energy Transition: The Case of the Boston Area. Energies 2020, 13, 2615. [CrossRef]

37. Valiño, L.; Sarasa, C.; Duarte, R. Economy-wide effects of a sustainable pathway in the pig sector: A case study in Aragon (Spain). J. Environ. Manag. 2019, 239, 84-89. [CrossRef] [PubMed]

38. Tańczuk, M.; Skorek, J.; Bargiel, P. Energy and economic optimization of the repowering of coal-fired municipal district heating source by a gas turbine. Energy Convers. Manag. 2017, 149, 885-895. [CrossRef]

39. Sibilio, S.; Rosato, A.; Ciampi, G.; Entchev, E.; Ribberink, H. Energy, Environmental and Economic Performance of a Micro-trigeneration System upon Varying the Electric Vehicle Charging Profiles. J. Sustain. Dev. Energy Water Environ. Syst. 2017, 5, 309-331. [CrossRef]

40. Carriço, J.; Fernandes, J.; Fernandes, C.; Branco, P.J.C. Technical and Economic Assessment of a $450 \mathrm{~W}$ Autonomous Photovoltaic System with Lithium Iron Phosphate Battery Storage. J. Sustain. Dev. Energy Water Environ. Syst. 2017, 6, 129-149. [CrossRef] 
41. Roefs, P.; Moretti, M.; Welkenhuysen, K.; Piessens, K.; Compernolle, T. $\mathrm{CO}_{2}$-enhanced oil recovery and $\mathrm{CO}_{2}$ capture and storage: An environmental economic trade-off analysis. J. Environ. Manag. 2019, 239, 167-177. [CrossRef]

42. Giacalone, F.; Papapetrou, M.; Kosmadakis, G.; Tamburini, A.; Micale, G.; Cipollina, A. Application of reverse electrodialysis to site-specific types of saline solutions: A techno-economic assessment. Energy 2019, 181, 532-547. [CrossRef]

43. Tańczuk, M.; Kostowski, W.; Karaś, M. Applying waste heat recovery system in a sewage sludge dryer-A technical and economic optimization. Energy Convers. Manag. 2016, 125, 121-132. [CrossRef]

44. Calise, F.; Figaj, R.D.; Vanoli, L. A novel polygeneration system integrating photovoltaic/thermal collectors, solar assisted heat pump, adsorption chiller and electrical energy storage: Dynamic and energy-economic analysis. Energy Convers. Manag. 2017, 149, 798-814. [CrossRef]

45. Carotenuto, A.; Figaj, R.D.; Vanoli, L. A novel solar-geothermal district heating, cooling and domestic hot water system: Dynamic simulation and energy-economic analysis. Energy 2017, 141, 2652-2669. [CrossRef]

46. Sibilio, S.; Rosato, A.; Ciampi, G.; Scorpio, M.; Akisawa, A. Building-integrated trigeneration system: Energy, environmental and economic dynamic performance assessment for Italian residential applications. Renew. Sustain. Energy Rev. 2017, 68, 920-933. [CrossRef]

47. Teixeira, A.M.; Arinelli, L.D.O.; De Medeiros, J.L.; Araújo, O.D.Q.F. Economic leverage affords post-combustion capture of $43 \%$ of carbon emissions: Supersonic separators for methanol hydrate inhibitor recovery from raw natural gas and $\mathrm{CO}_{2}$ drying. J. Environ. Manag. 2019, 236, 534-550. [CrossRef] [PubMed]

48. Dozic, D.J.; Urosevic, B.D.G. Application of artificial neural networks for testing long-term energy policy targets. Energy 2019, 174, 488-496. [CrossRef]

49. Wiesberg, I.L.; Brigagão, G.V.; De Medeiros, J.L.; Araújo, O.D.Q.F. Carbon dioxide utilization in a microalga-based biorefinery: Efficiency of carbon removal and economic performance under carbon taxation. J. Environ. Manag. 2017, 203, 988-998. [CrossRef] [PubMed]

50. Larrain, M.; Van Passel, S.; Thomassen, G.; Kresovic, U.; Alderweireldt, N.; Moerman, E.; Billen, P. Economic performance of pyrolysis of mixed plastic waste: Open-loop versus closed-loop recycling. J. Clean. Prod. 2020, 270, 122442. [CrossRef]

51. Bertheau, P. Supplying not electrified islands with $100 \%$ renewable energy based micro grids: A geospatial and techno-economic analysis for the Philippines. Energy 2020, 202, 117670. [CrossRef]

52. Picallo-Perez, A.; Catrini, P.; Piacentino, A.; Sala, J.M. A novel thermoeconomic analysis under dynamic operating conditions for space heating and cooling systems. Energy 2019, 180, 819-837. [CrossRef]

53. Kuang, Y.; Yen, B.T.; Suprun, E.; Sahin, O. A soft traffic management approach for achieving environmentally sustainable and economically viable outcomes: An Australian case study. J. Environ. Manag. 2019, 237, 379-386. [CrossRef] [PubMed]

54. Chang, K.-H.; Lou, K.-R.; Ko, C.-H. Potential of bioenergy production from biomass wastes of rice paddies and forest sectors in Taiwan. J. Clean. Prod. 2019, 206, 460-476. [CrossRef]

55. Chan, K.-L.; Dong, C.; Wong, M.S.; Kim, L.-H.; Leu, S.-Y. Plant chemistry associated dynamic modelling to enhance urban vegetation carbon sequestration potential via bioenergy harvesting. J. Clean. Prod. 2018, 197, 1084-1094. [CrossRef]

56. Szulczewski, W.; Żyromski, A.; Jakubowski, W.; Biniak-Pieróg, M. A new method for the estimation of biomass yield of giant miscanthus ( Miscanthus giganteus ) in the course of vegetation. Renew. Sustain. Energy Rev. 2018, 82, 1787-1795. [CrossRef]

57. Borsukiewicz, A.; Klonowicz, P.; Król, D.; Wiśniewski, S.; Zwarycz-Makles, K. Techno-economic analysis of CHP system supplied by waste forest biomass. Waste Manag. Res. 2015, 33, 748-754. [CrossRef] [PubMed]

58. Striūgas, N.; Vorotinskienè, L.; Paulauskas, R.; Navakas, R.; Džiugys, A.; Narbutas, L. Estimating the fuel moisture content to control the reciprocating grate furnace firing wet woody biomass. Energy Convers. Manag. 2017, 149, 937-949. [CrossRef]

59. Luz, F.C.; Cordiner, S.; Manni, A.; Mulone, V.; Rocco, V. Biomass fast pyrolysis in screw reactors: Prediction of spent coffee grounds bio-oil production through a monodimensional model. Energy Convers. Manag. 2018, 168, 98-106. [CrossRef]

60. Chng, L.M.; Chan, D.J.C.; Lee, K.T. Sustainable production of bioethanol using lipid-extracted biomass from Scenedesmus dimorphus. J. Clean. Prod. 2016, 130, 68-73. [CrossRef] 
61. Peralta-Ruiz, Y.; González-Delgado, A.-D.; Kafarov, V. Evaluation of alternatives for microalgae oil extraction based on exergy analysis. Appl. Energy 2013, 101, 226-236. [CrossRef]

62. Wzorek, M.; Tańczuk, M. Production of biosolid fuels from municipal sewage sludge: Technical and economic optimisation. Waste Manag. Res. 2015, 33, 704-714. [CrossRef]

63. Silva, C.; Ferreira, A.F.; Dias, A.P.S.; Costa, M. A comparison between microalgae virtual biorefinery arrangements for bio-oil production based on lab-scale results. J. Clean. Prod. 2016, 130, 58-67. [CrossRef]

64. Eggemann, L.; Escobar, N.; Peters, R.; Burauel, P.; Stolten, D. Life cycle assessment of a small-scale methanol production system: A power-to-fuel strategy for biogas plants. J. Clean. Prod. 2020, 271, 122476. [CrossRef]

65. Kazagic, A.; Music, M.; Smajevic, I.; Ademovic, A.; Redzic, E. Possibilities and sustainability of "biomass for power" solutions in the case of a coal-based power utility. Clean Technol. Environ. Policy 2016, 18, 1675-1683. [CrossRef]

66. Hussain, C.I.; Norton, B.; Duffy, A. Technological assessment of different solar-biomass systems for hybrid power generation in Europe. Renew. Sustain. Energy Rev. 2017, 68, 1115-1129. [CrossRef]

67. Aste, N.; Caputo, P.; Del Pero, C.; Ferla, G.; Huerto-Cardenas, H.E.; Leonforte, F.; Miglioli, A. A renewable energy scenario for a new low carbon settlement in northern Italy: Biomass district heating coupled with heat pump and solar photovoltaic system. Energy 2020, 206, 118091. [CrossRef]

68. Milani, M.; Montorsi, L. Energy Recovery of the Biomass from Livestock Farms in Italy: The Case of Modena Province. J. Sustain. Dev. Energy Water Environ. Syst. 2018, 6, 464-480. [CrossRef]

69. Pfeifer, A.; Dominković, D.F.; Ćosić, B.; Duić, N. Economic feasibility of CHP facilities fueled by biomass from unused agriculture land: Case of Croatia. Energy Convers. Manag. 2016, 125, 222-229. [CrossRef]

70. Ooba, M.; Fujii, M.; Hayashi, K. Geospatial distribution of ecosystem services and biomass energy potential in eastern Japan. J. Clean. Prod. 2016, 130, 35-44. [CrossRef]

71. Yang, D.; Jia, X.; Dang, M.; Han, F.; Shi, F.; Tanikawa, H.; Klemeš, J.J. Life cycle assessment of cleaner production measures in monosodium glutamate production: A case study in China. J. Clean. Prod. 2020, 270, 122126. [CrossRef]

72. Kılkış, Ş. Sustainability-oriented innovation system analyses of Brazil, Russia, India, China, South Africa, Turkey and Singapore. J. Clean. Prod. 2016, 130, 235-247. [CrossRef]

73. Mikulandric, R.; Böhning, D.; Böhme, R.; Helsen, L.; Beckmann, M.; Loncar, D. Dynamic modelling of biomass gasification in a co-current fixed bed gasifier. Energy Convers. Manag. 2016, 125, 264-276. [CrossRef]

74. La Villetta, M.; Costa, M.; Cirillo, D.; Massarotti, N.; Vanoli, L. Performance analysis of a biomass powered micro-cogeneration system based on gasification and syngas conversion in a reciprocating engine. Energy Convers. Manag. 2018, 175, 33-48. [CrossRef]

75. Vukasinovic, V.; Gordic, D.; Zivkovic, M.; Koncalovic, D.; Zivkovic, D. Long-term planning methodology for improving wood biomass utilization. Energy 2019, 175, 818-829. [CrossRef]

76. Ancona, V.; Caracciolo, A.B.; Campanale, C.; De Caprariis, B.; Grenni, P.; Uricchio, V.F.; Borello, D. Gasification treatment of poplar biomass produced in a contaminated area restored using plant assisted bioremediation. J. Environ. Manag. 2019, 239, 137-141. [CrossRef]

77. Caputo, P.; Ferla, G.; Ferrari, S. Evaluation of environmental and energy effects of biomass district heating by a wide survey based on operational conditions in Italy. Energy 2019, 174, 1210-1218. [CrossRef]

78. Wang, Y.; Tan, H.; Wang, X.; Du, W.; Mikulčić, H.; Duić, N. Study on extracting available salt from straw/woody biomass ashes and predicting its slagging/fouling tendency. J. Clean. Prod. 2017, 155, 164-171. [CrossRef]

79. Mikulandrić, R.; Vermeulen, B.; Nicolai, B.; Saeys, W. Modelling of thermal processes during extrusion based densification of agricultural biomass residues. Appl. Energy 2016, 184, 1316-1331. [CrossRef]

80. Tomasek, S.; Lónyi, F.; Valyon, J.; Hancsók, J. Fuel purpose hydrocracking of biomass based Fischer-Tropsch paraffin mixtures on bifunctional catalysts. Energy Convers. Manag. 2020, 213, 112775. [CrossRef]

81. Ko, C.-H.; Chaiprapat, S.; Kim, L.-H.; Hadi, P.; Hsu, S.-C.; Leu, S.-Y. Carbon sequestration potential via energy harvesting from agricultural biomass residues in Mekong River basin, Southeast Asia. Renew. Sustain. Energy Rev. 2017, 68, 1051-1062. [CrossRef]

82. Zhu, Y.; Tan, H.; Niu, Y.; Wang, Y.; Mikulčić, H.; Vujanović, M.; Duić, N. Modelling study on the effect of ash fusion characteristics on the biomass slagging behavior. Therm. Sci. 2018, 22, 2113-2121. [CrossRef]

83. Růžičková, J.; Kucbel, M.; Raclavská, H.; Švédová, B.; Raclavský, K.; Juchelková, D. Comparison of organic compounds in char and soot from the combustion of biomass in boilers of various emission classes. J. Environ. Manag. 2019, 236, 769-783. [CrossRef] [PubMed] 
84. Wang, X.; Jin, Q.; Wang, L.; Bai, S.; Mikulčić, H.; Vujanović, M.; Wang, X. Synergistic effect of biomass and polyurethane waste co-pyrolysis on soot formation at high temperatures. J. Environ. Manag. 2019, 239, 306-315. [CrossRef] [PubMed]

85. Zambrana-Vasquez, D.; Zabalza-Bribián, I.; Jañez, A.; Aranda-Usón, A. Analysis of the environmental performance of life-cycle building waste management strategies in tertiary buildings. J. Clean. Prod. 2016, 130, 143-154. [CrossRef]

86. Gourlis, G.; Kovacic, I. A study on building performance analysis for energy retrofit of existing industrial facilities. Appl. Energy 2016, 184, 1389-1399. [CrossRef]

87. Marrasso, E.; Roselli, C.; Sasso, M.; Tariello, F. Comparison of centralized and decentralized air-conditioning systems for a multi-storey/multi users building integrated with electric and diesel vehicles and considering the evolution of the national energy system. Energy 2019, 177, 319-333. [CrossRef]

88. Chong, H.-Y.; Wang, X. The outlook of building information modeling for sustainable development. Clean Technol. Environ. Policy 2016, 18, 1877-1887. [CrossRef]

89. Herrando, M.; Cambra, D.; Navarro, M.; De La Cruz, L.; Millán, G.; Zabalza, I.; Bribián, I.Z. Energy Performance Certification of Faculty Buildings in Spain: The gap between estimated and real energy consumption. Energy Convers. Manag. 2016, 125, 141-153. [CrossRef]

90. Borjigin, S.; Zhang, S.; Ma, T.; Zeng, M.; Wang, Q. Performance enhancement of cabinet cooling system by utilizing cross-flow plate heat exchanger. Energy Convers. Manag. 2020, 213, 112854. [CrossRef]

91. Horvat, I.; Dović, D. Dynamic modeling approach for determining buildings technical system energy performance. Energy Convers. Manag. 2016, 125, 154-165. [CrossRef]

92. Ferrari, S.; Zagarella, F.; Caputo, P.; D'Amico, A. Results of a literature review on methods for estimating buildings energy demand at district level. Energy 2019, 175, 1130-1137. [CrossRef]

93. Barone, G.; Buonomano, A.; Forzano, C.; Palombo, A. Enhancing trains envelope-Heating, ventilation, and air conditioning systems: A new dynamic simulation approach for energy, economic, environmental impact and thermal comfort analyses. Energy 2020, 204, 117833. [CrossRef]

94. Gourlis, G.; Kovacic, I. Passive measures for preventing summer overheating in industrial buildings under consideration of varying manufacturing process loads. Energy 2017, 137, 1175-1185. [CrossRef]

95. De Guinoa, A.S.; Zambrana-Vasquez, D.; Alcalde, A.; Corradini, M.; Bribián, I.Z. Environmental assessment of a nano-technological aerogel-based panel for building insulation. J. Clean. Prod. 2017, 161, 1404-1415. [CrossRef]

96. Berardi, U.; Tronchin, L.; Manfren, M.; Nastasi, B. On the Effects of Variation of Thermal Conductivity in Buildings in the Italian Construction Sector. Energies 2018, 11, 872. [CrossRef]

97. Pavičević, M.; Novosel, T.; Pukšec, T.; Duic, N. Hourly optimization and sizing of district heating systems considering building refurbishment-Case study for the city of Zagreb. Energy 2017, 137, 1264-1276. [CrossRef]

98. Gil-Baez, M.; Barrios-Padura, Á.; Molina-Huelva, M.; Chacartegui, R. Natural ventilation systems in 21st-century for near zero energy school buildings. Energy 2017, 137, 1186-1200. [CrossRef]

99. Kilkis, B. Exergy-Optimum Coupling of Heat Recovery Ventilation Units with Heat Pumps in Sustainable Buildings. J. Sustain. Dev. Energy Water Environ. Syst. 2020, 8, 815-845. [CrossRef]

100. Sholahudin, S.; Han, H. Simplified dynamic neural network model to predict heating load of a building using Taguchi method. Energy 2016, 115, 1672-1678. [CrossRef]

101. Gourlis, G.; Kovacic, I. Building Information Modelling for analysis of energy efficient industrial buildings-A case study. Renew. Sustain. Energy Rev. 2017, 68, 953-963. [CrossRef]

102. Krstić-Furundžić, A.; Vujosevic, M.; Petrovski, A. Energy and environmental performance of the office building facade scenarios. Energy 2019, 183, 437-447. [CrossRef]

103. Asfour, O.S. Proposed Measures to Protect Temporary Roofs from Unwanted Heat Gains. J. Sustain. Dev. Energy Water Environ. Syst. 2017, 5, 191-201. [CrossRef]

104. Ramos, J.; Aires, L. The Effect of a Naturally Ventilated Roof on the Thermal Behaviour of a Building under Mediterranean Summer Conditions. J. Sustain. Dev. Energy Water Environ. Syst. 2020, 8, 508-519. [CrossRef]

105. Zagarella, P.C.S.F.G.F.F. Preliminary Energy Evaluations for the Retrofit of Rural Protected Buildings in a Peripheral Context of Milan. J. Sustain. Dev. Energy Water Environ. Syst. 2020, 8, 715-734.

106. Tettey, U.Y.A.; Gustavsson, L. Energy savings and overheating risk of deep energy renovation of a multi-storey residential building in a cold climate under climate change. Energy 2020, 202, 117578. [CrossRef] 
107. Bottino-Leone, D.; Larcher, M.; Herrera-Avellanosa, D.; Haas, F.; Troi, A. Evaluation of natural-based internal insulation systems in historic buildings through a holistic approach. Energy 2019, 181, 521-531. [CrossRef]

108. Piselli, C.; Pisello, A.L. Occupant behavior long-term continuous monitoring integrated to prediction models: Impact on office building energy performance. Energy 2019, 176, 667-681. [CrossRef]

109. Cipek, M.; Pavković, D.; Kljaić, Z.; Mlinarić, T.J. Assessment of battery-hybrid diesel-electric locomotive fuel savings and emission reduction potentials based on a realistic mountainous rail route. Energy 2019, 173, 1154-1171. [CrossRef]

110. Zvar-Baskovic, U.; Vihar, R.; Rodman-Opresnik, S.; Katrašnik, T. Simultaneous particulate matter and nitrogen oxide emission reduction through enhanced charge homogenization in diesel engines. Therm. Sci. 2018, 22, 2039-2052. [CrossRef]

111. Bekteshi, S.; Kabashi, S.; Ahmetaj, S.; Slaus, I.; Zidansek, A.; Podrimqaku, K.; Kastrati, S. Dynamic Modeling of Kosovo's Electricity Supply-Demand, Gaseous Emissions and Air Pollution. J. Sustain. Dev. Energy Water Environ. Syst. 2015, 3, 303-314. [CrossRef]

112. Branco, V.; Costa, M. Effect of particle size on the burnout and emissions of particulate matter from the combustion of pulverized agricultural residues in a drop tube furnace. Energy Convers. Manag. 2017, 149, 774-780. [CrossRef]

113. Walmsley, M.R.; Walmsley, T.G.; Atkins, M.J. Linking greenhouse gas emissions footprint and energy return on investment in electricity generation planning. J. Clean. Prod. 2018, 200, 911-921. [CrossRef]

114. Ajanovic, A.; Haas, R. The impact of energy policies in scenarios on GHG emission reduction in passenger car mobility in the EU-15. Renew. Sustain. Energy Rev. 2017, 68, 1088-1096. [CrossRef]

115. Galic, M.; Bilandzija, D.; Percin, A.; Sestak, I.; Mesic, M.; Blazinkov, M.; Zgorelec, Z. Effects of Agricultural Practices on Carbon Emission and Soil Health. J. Sustain. Dev. Energy Water Environ. Syst. 2019, 7, 539-552. [CrossRef]

116. Bonaventura, D.; Chacartegui, R.; Valverde, J.; Becerra, J.; Ortíz, C.; Lizana, J. Dry carbonate process for $\mathrm{CO}_{2}$ capture and storage: Integration with solar thermal power. Renew. Sustain. Energy Rev. 2018, 82, 1796-1812. [CrossRef]

117. Interlenghi, S.F.; Silva, R.D.P.F.; De Medeiros, J.L.; Araújo, O.D.Q.F. Low-emission offshore Gas-To-Wire from natural gas with carbon dioxide: Supersonic separator conditioning and post-combustion decarbonation. Energy Convers. Manag. 2019, 195, 1334-1349. [CrossRef]

118. Petranović, Z.; Bešenić, T.; Vujanović, M.; Duić, N. Modelling pollutant emissions in diesel engines, influence of biofuel on pollutant formation. J. Environ. Manag. 2017, 203, 1038-1046. [CrossRef]

119. Vujanović, M.; Petranović, Z.; Edelbauer, W.; Duić, N. Modelling spray and combustion processes in diesel engine by using the coupled Eulerian-Eulerian and Eulerian-Lagrangian method. Energy Convers. Manag. 2016, 125, 15-25. [CrossRef]

120. Chen, A.F.; Adzmi, M.A.; Adam, A.; Othman, M.F.; Kamaruzzaman, M.K.; Mrwan, A.G. Combustion characteristics, engine performances and emissions of a diesel engine using nanoparticle-diesel fuel blends with aluminium oxide, carbon nanotubes and silicon oxide. Energy Convers. Manag. 2018, 171, 461-477. [CrossRef]

121. Vihar, R.; Baškovič, U.Ž.; Seljak, T.; Katrašnik, T. Combustion and emission formation phenomena of tire pyrolysis oil in a common rail Diesel engine. Energy Convers. Manag. 2017, 149, 706-721. [CrossRef]

122. Yin, C. Development in biomass preparation for suspension firing towards higher biomass shares and better boiler performance and fuel rangeability. Energy 2020, 196, 117129. [CrossRef]

123. Somogyi, V.; Sebestyén, V.; Kovács, Z.; Hargitai, R.H.; Domokos, E. Enhanced Pollution Removal with Heat Reclamation in a Small Hungarian Wastewater Treatment Plant. J. Sustain. Dev. Energy Water Environ. Syst. 2018, 6, 494-504. [CrossRef]

124. Pukšec, T.; Mathiesen, B.V.; Novosel, T.; Duić, N. Assessing the impact of energy saving measures on the future energy demand and related GHG (greenhouse gas) emission reduction of Croatia. Energy 2014, 76, 198-209. [CrossRef]

125. Schneider, D.R.; Kirac, M.; Hublin, A. Cost-effectiveness of GHG emission reduction measures and energy recovery from municipal waste in Croatia. Energy 2012, 48, 203-211. [CrossRef]

126. Gładysz, P.; Ziębik, A. Life cycle assessment of an integrated oxy-fuel combustion power plant with $\mathrm{CO}_{2}$ capture, transport and storage-Poland case study. Energy 2015, 92, 328-340. [CrossRef] 
127. Nawi, W.N.R.M.; Alwi, S.R.W.; Manan, Z.A.; Klemeš, J.J. A systematic technique for cost-effective $\mathrm{CO}_{2}$ emission reduction in process plants. Clean Technol. Environ. Policy 2016, 18, 1769-1777. [CrossRef]

128. Van Fan, Y.; Perry, S.; Klemeš, J.; Lee, C.T. A review on air emissions assessment: Transportation. J. Clean. Prod. 2018, 194, 673-684. [CrossRef]

129. Van Fan, Y.; Tan, R.; Klemeš, J.J. A system analysis tool for sustainable biomass utilisation considering the Emissions-Cost Nexus. Energy Convers. Manag. 2020, 210, 112701. [CrossRef]

130. Tronchin, L.; Manfren, M.; Nastasi, B. Energy efficiency, demand side management and energy storage technologies-A critical analysis of possible paths of integration in the built environment. Renew. Sustain. Energy Rev. 2018, 95, 341-353. [CrossRef]

131. Buonomano, A.; Calise, F.; D'Accadia, M.D.; Vicidomini, M. A hybrid renewable system based on wind and solar energy coupled with an electrical storage: Dynamic simulation and economic assessment. Energy 2018, 155, 174-189. [CrossRef]

132. Sorknaes, P. Simulation method for a pit seasonal thermal energy storage system with a heat pump in a district heating system. Energy 2018, 152, 533-538. [CrossRef]

133. Milis, K.; Peremans, H.; Springael, J.; Van Passel, S. Win-win possibilities through capacity tariffs and battery storage in microgrids. Renew. Sustain. Energy Rev. 2019, 113, 109238. [CrossRef]

134. Kokalj, F.; Arbiter, B.; Samec, N. Sewage sludge gasification as an alternative energy storage model. Energy Convers. Manag. 2017, 149, 738-747. [CrossRef]

135. Marino, C.; Nucara, A.; Panzera, M.; Pietrafesa, M.; Varano, V. Energetic and economic analysis of a stand alone photovoltaic system with hydrogen storage. Renew. Energy 2019, 142, 316-329. [CrossRef]

136. Moser, M.; Gils, H.-C.; Pivaro, G. A sensitivity analysis on large-scale electrical energy storage requirements in Europe under consideration of innovative storage technologies. J. Clean. Prod. 2020, 269, 122261. [CrossRef]

137. Jin, T.-H.; Chung, M.; Shin, K.-Y.; Park, H.; Lim, G.-P. Real-Time Dynamic Simulation of Korean Power Grid for Frequency Regulation Control by MW Battery Energy Storage System. J. Sustain. Dev. Energy Water Environ. Syst. 2016, 4, 392-407. [CrossRef]

138. Luburić, Z.; Pandžić, H.; Plavšić, T.; Teklić, L.; Valentić, V. Role of energy storage in ensuring transmission system adequacy and security. Energy 2018, 156, 229-239. [CrossRef]

139. Milis, K.; Peremans, H.; Van Passel, S. Steering the adoption of battery storage through electricity tariff design. Renew. Sustain. Energy Rev. 2018, 98, 125-139. [CrossRef]

140. Buonomano, A.; Calise, F.; Cappiello, F.; Palombo, A.; Vicidomini, M. Dynamic analysis of the integration of electric vehicles in efficient buildings fed by renewables. Appl. Energy 2019, 245, 31-50. [CrossRef]

141. Calise, F.; Cappiello, F.L.; Cartenì, A.; D’Accadia, M.D.; Vicidomini, M. A novel paradigm for a sustainable mobility based on electric vehicles, photovoltaic panels and electric energy storage systems: Case studies for Naples and Salerno (Italy). Renew. Sustain. Energy Rev. 2019, 111, 97-114. [CrossRef]

142. Gil Posada, J.O.; Rennie, A.J.R.; Villar, S.P.; Martins, V.L.; Marinaccio, J.; Barnes, A.; Glover, C.F.; Worsley, D.A.; Hall, P.J. Aqueous batteries as grid scale energy storage solutions. Renew. Sustain. Energy Rev. 2017, 68, 1174-1182. [CrossRef]

143. Moser, S.; Mayrhofer, J.; Schmidt, R.; Tichler, R. Socioeconomic cost-benefit-analysis of seasonal heat storages in district heating systems with industrial waste heat integration. Energy 2018, 160, 868-874. [CrossRef]

144. Scharinger-Urschitz, G.; Walter, H.; Brier, J. Experimental investigation on bimetallic tube compositions for the use in latent heat thermal energy storage units. Energy Convers. Manag. 2016, 125, 368-378. [CrossRef]

145. Mehari, A.; Xu, Z.; Wang, R. Thermal energy storage using absorption cycle and system: A comprehensive review. Energy Convers. Manag. 2020, 206, 112482. [CrossRef]

146. Dominković, D.F.; Krajačić, G. District Cooling Versus Individual Cooling in Urban Energy Systems: The Impact of District Energy Share in Cities on the Optimal Storage Sizing. Energies 2019, 12, 407. [CrossRef]

147. Böhm, H.; Lindorfer, J. Techno-economic assessment of seasonal heat storage in district heating with thermochemical materials. Energy 2019, 179, 1246-1264. [CrossRef]

148. Restrepo-Valencia, S.; Walter, A.C.S. Techno-Economic Assessment of Bio-Energy with Carbon Capture and Storage Systems in a Typical Sugarcane Mill in Brazil. Energies 2019, 12, 1129. [CrossRef]

149. Pospíšil, J.; Charvát, P.; Arsenyeva, O.; Klimeš, L.; Špiláček, M.; Klemeš, J.J. Energy demand of liquefaction and regasification of natural gas and the potential of LNG for operative thermal energy storage. Renew. Sustain. Energy Rev. 2019, 99, 1-15. [CrossRef] 
150. Carneiro, J.F.; Matos, C.R.; Van Gessel, S. Opportunities for large-scale energy storage in geological formations in mainland Portugal. Renew. Sustain. Energy Rev. 2019, 99, 201-211. [CrossRef]

151. Wagner, O.; Adisorn, T.; Tholen, L.; Kiyar, D. Surviving the Energy Transition: Development of a Proposal for Evaluating Sustainable Business Models for Incumbents in Germany's Electricity Market. Energies 2020, 13, 730. [CrossRef]

152. Podbregar, I.; Šimić, G.; Radovanović, M.; Filipović, S.; Šprajc, P. International Energy Security Risk Index-Analysis of the Methodological Settings. Energies 2020, 13, 3234. [CrossRef]

153. Asatani, K.; Takeda, H.; Yamano, H.; Sakata, I. Scientific Attention to Sustainability and SDGs: Meta-Analysis of Academic Papers. Energies 2020, 13, 975. [CrossRef]

154. Alrefai, R.; Alrefai, A.; Benyounis, K.; Stokes, J. An Evaluation of the Effects of the Potato Starch on the Biogas Produced from the Anaerobic Digestion of Potato Wastes. Energies 2020, 13, 2399. [CrossRef]

155. Alrefai, A.; Alrefai, R.; Benyounis, K.; Stokes, J. Impact of Starch from Cassava Peel on Biogas Produced through the Anaerobic Digestion Process. Energies 2020, 13, 2713. [CrossRef]

156. Roselli, C.; Sasso, M.; Tariello, F. A Wind Electric-Driven Combined Heating, Cooling, and Electricity System for an Office Building in Two Italian Cities. Energies 2020, 13, 895. [CrossRef]

157. Vella, C.; Borg, S.P.; Micallef, D. The Effect of Shank-Space on the Thermal Performance of Shallow Vertical U-Tube Ground Heat Exchangers. Energies 2020, 13, 602. [CrossRef]

158. Djorup, S.; Sperling, K.; Nielsen, S.; Ostergaard, P.A.; Thellufsen, J.Z.; Sorknaes, P.; Lund, H.; Drysdale, D. District Heating Tariffs, Economic Optimisation and Local Strategies during Radical Technological Change. Energies 2020, 13, 1172. [CrossRef]

159. Pucko, Z.; Maucec, D.; Suman, N. Energy and Cost Analysis of Building Envelope Components Using BIM: A Systematic Approach. Energies 2020, 13, 2643. [CrossRef]

160. Arnaiz-Del-Pozo, C.; Jiménez, Á.; Cloete, S.; Cloete, J.H.; Amini, S. Exergy Analysis of Gas Switching Chemical Looping IGCC Plants. Energies 2020, 13, 544. [CrossRef]

161. Jozic, P.; Zidansek, A.; Repnik, R. Fuel Conservation for Launch Vehicles: Falcon Heavy Case Study. Energies 2020, 13, 660. [CrossRef]

162. Jamaluddin, K.; Alwi, S.R.W.; Hamzah, K.; Klemeš, J.J. A Numerical Pinch Analysis Methodology for Optimal Sizing of a Centralized Trigeneration System with Variable Energy Demands. Energies 2020, 13, 2038. [CrossRef]

163. Hofmann, F.; Schlott, M.; Kies, A.; Stöcker, H. Flow Allocation in Meshed AC-DC Electricity Grids. Energies 2020, 13, 1233. [CrossRef]

164. Calise, F.; Cappiello, F.L.; Vanoli, R.; Vicidomini, M. Economic assessment of renewable energy systems integrating photovoltaic panels, seawater desalination and water storage. Appl. Energy 2019, 253, 253. [CrossRef]

165. Calise, F.; D’Accadia, M.D.; Vanoli, R.; Vicidomini, M. Transient analysis of solar polygeneration systems including seawater desalination: A comparison between linear Fresnel and evacuated solar collectors. Energy 2019, 172, 647-660. [CrossRef]

166. Calise, F.; D'Accadia, M.D.; Vicidomini, M.; Ferruzzi, G.; Vanoli, L. Design and Dynamic Simulation of a Combined System Integration Concentrating Photovoltaic/Thermal Solar Collectors and Organic Rankine Cycle. Am. J. Eng. Appl. Sci. 2015, 8, 100-118. [CrossRef]

(C) 2020 by the authors. Licensee MDPI, Basel, Switzerland. This article is an open access article distributed under the terms and conditions of the Creative Commons Attribution (CC BY) license (http://creativecommons.org/licenses/by/4.0/). 